\title{
المجمل والمبين في القرآن سورة (الفتح) أنموذجاً دراسة تطبيقية
}

\author{
كئِيُ إعداد الباحثة

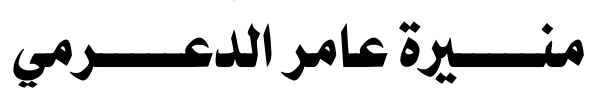 \\ المحاضرة بقسم الدراسات القرآنية ـ كلية الآداب والإدارة \\ جامعة بيشة، بيشة، الملكة العربية السعودية \\ Zxvb299@gmail.com
}




\section{المجمل والمبين في القرآن سورة (الفتح) أنموذجاً دراسة تطبيقية}

منيرة عامر الاعرمي

قسم الدراسات القرآنية - كلية الآداب والإدارة ببيشة - جامعة بيشة، بيشة،

المملكة العربية السعودية.

البريد الاليكتروني : Zxvb299@gmail.com الملخص:

يتناول هذا البحث موضوع البحمل والمبين في سورة (الفتح)، وفيه تكشف الباحثة اللثام عـن مصطلحي الدراسـة (البحمـل، المبــن) عـبر سـبر عميـق لأقوال اللغويين والمفسرين فيهمـا. حيـث يكتسبب كل مـن الاصطلاحين أهميـة كبيرة في بحـالين شـرعيين هما : التفسير والفقه وأصوله. وقد سعت الباحثة إلى بيان البحمل تطبيقيا من خلال استيعاب ما في سورة (الفتح) مس مواطن الاجمـال فكانت اثنتي عشرة موضع. وانصب عملي على بيـان اجمالهـا مـن خـلال بيـان وجـهـ الاجمـال ثم تعقـب كـل موضـع منهـا ببيـان واستيعاب الأقوال المعتبرة فيه والتي جاءت لبيان اجمال المفردة أو الموضع القرآي. كما رصدت الباحثة القول الراجح عند أسـاطين التفسير مبينة وجـه لرجيح المتخـذ سبيلا لبيـان بحمـل ذلك اللفظظ القـرآي على هـــي مـن تفـسير القـرآن بـالقرآن مـع اعمـال دلالات السياق واللغة فيما يخدم الترجيح والتوفيق بين الأقوال. الكلمات المفتاحية : التفسير - البحمل - المبين - سورة (الفتح) - غريب القرآن. 


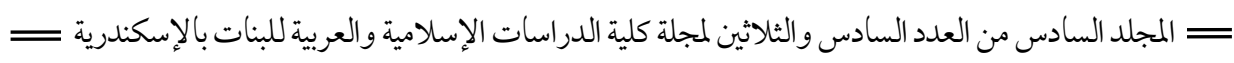

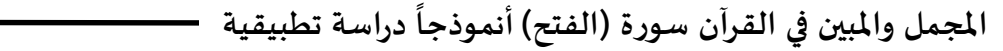

\section{Outline and outlined in the Koran Surat (Alfath) a model An Empirical Study}

Munira Amer Al-Darami

Lecture, Quranic Studies Department

Bisha College of Arts and Administration

Bisha University, Bisha, Saudi Arabia

e.mail: Zxvb299@gmail.com

\section{abstract:}

This research deals with the subject of the totality and described in Surat (Alfath), in which the researcher reveals the terms of the study (totality, shown) through a deep sounding of the words of the linguists and interpreters therein. Each of the two terms is of great importance in two legitimate areas: interpretation and jurisprudence and its origins. The researcher sought to explain the totality by applying the absorption in the Surat (Alhujorat) of the total of Twelve places. Its work focused on the statement of its totality through the statement of the total and then track each of them with a statement and absorb the words considered in it, which came to indicate the totality of the individual or the Koranic position. The researcher also spotted the most correct statement when the interpreters clarified the face of the likelihood of taking a way to indicate the overall Quranic word guided by the interpretation of the Koran in the Koran with the semantics of context and language in favor of weighting and reconciliation of words.

Keywords: tafsir - almajmal - almubin - surah (Alfath) strange Quran 


\section{(1)}

الحمد لله الذي امتدح نفسه بتعليمنا القرآن وامتن على الإنسان بأن علمه البيان وقرن هذه النعمة بإنزال القرآن وخلقه الإنسان لقوله عز من قائل : (الرحمن علم القرآن خلق الإنسان علمه البيان)، كما امتدح سبحانه كتابه العزيز وأثنى عليه بالبيان لقوله لرنه جل شأنه (تلك آيات الكتاب المبين)، فجعل بيان كتابه وظيفة نبيه صلى الله عليه وسلم لقوله تعالى (قد أنزلنا إليكم ذكرا رسولا يتلو عليكم آيات الله مبينات).

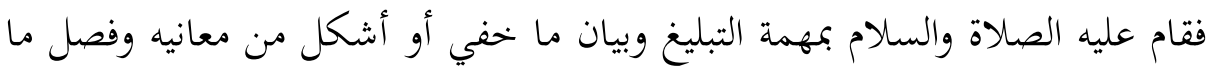
فيه من إجمال وتقييد لكي يفهمه المسلمون كما أراده رب العزة، وذلك لقوله تعالى

\section{(وأنزلنا إليك الذكر لتبين للناس ما نزل إليهم ولعلهم يتفكرون)}

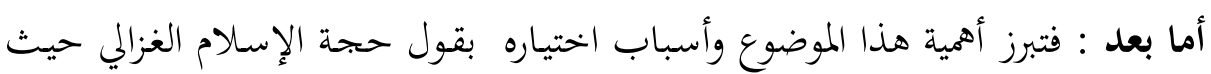
يقول: (يجتاج إلى البيان كل ما يتطرق إليه احتمال، كابلممل والمحاز والمنتول بتصرف الشرع، والعام المختمل للخصوص، والظاهر المتمل للتأويل) كما أن الاشتغال ببيان

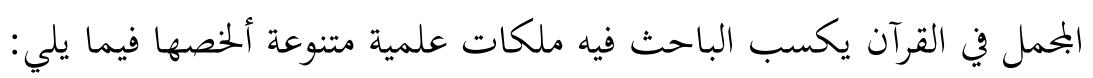

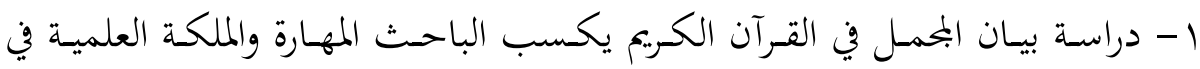
تحليل النصوص، وإخراجها إذ إنه يتجاذب بين الكتاب والسنة والفقه والأصول

$$
\text { والتدبر والاستنباط وغيرها. }
$$

ץ-دراسـة بيـان البممـل في القـرآن الكـريم تطبيقـا تكسب الباحـث المنهجيـة العلميـة الصحيحة في التعامل مع المجمل و المبين كما أها تبرز كثيرا من النتائج و الفوائد. r- إزالة اللبس و دفع التوهم، في فهم نصوص الكتاب العزيز واستنباط معان جديدة 
ع - جدة الموضوع، حيث البحث فيه قليل جدا، فيفتقر إلى خدمة، فأردت الاسهام في هذا العلم النافع والاثر الجليل.

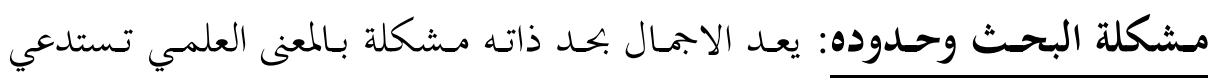

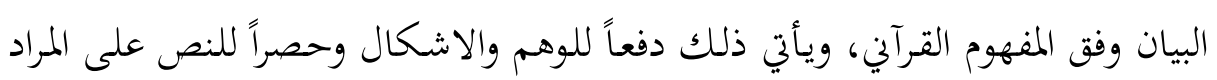
منه فلا يبقى اجماله محلاً لضلال الافهام وخوض القائلين بلا دليل أو برهان.

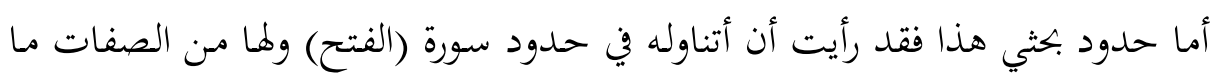

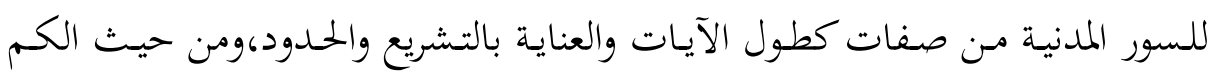
فهي من سور متوسطة الطول إذ تبلغ آياتا الكريمة تسعاً وعشرين آية. أهداف البحث : 1- بيـان النصوص البحملة من القرآن الكريم و إجلاء معانيها، وخاصة التي ظاهرها

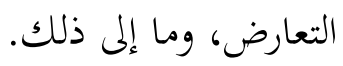
ץ- خدمة الدين، وبحال العلم، وخاصة الدراسات القرآنية، ومنح التفسير أفقاً جديداً من البيان ودفع أوهام التعارض المشكلة ب- خدمة الباحثين في توضيح النهج الأمثل عند التعرض للنصوص البحملة في القرآن الكريم، وتوضيح كيفية تبيينها.

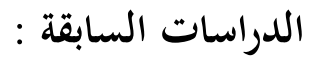
القسم الأول : مـا يتعلق بدراسة المجمل و المبين كفن مـستقل، فقـد كتب في ذلك

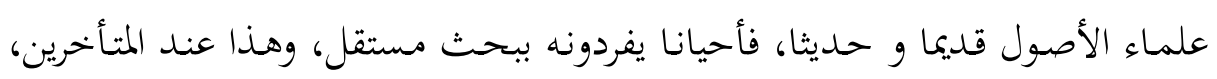
أو يصنفونه ضمن مباحثهم في علم الأصول.

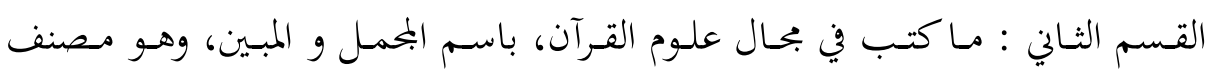
عندهم على منهجين : 
1- تصنيفه ضمن كتب علوم القرآن، كالزركشي في البرهان، و السيوطي في الإتقان،

$$
\text { وهم يكتفون بذكر الأسباب. }
$$

ץ- إفراده بمؤلف خاص وهذا عند المتأخرين، و في هذا وقفت بـت على رسالتين أحدهما :

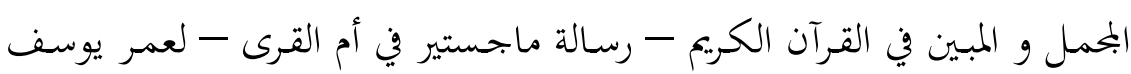

حمزة، و ثانيهما : البحمل و المبيت في القرآن الكريم - ماجستير - لعبد الفتاح

$$
\text { محمد خضر. }
$$

القسم الثالث : ما ألف في بيان البحمل من القرآن الكريع - دراسة تطبيقية -، ووقفت فقط على تفسير واحد اعتى بهذا الجانب : هو أضواء البيان في إيضاح القرآن بالقرآن " للعلامة محمد الشنقيطي - رمهه الله - . ثم مشروع الجامعة الإسلامية بالمدينة المنورة : و الذي بدأ من أول القرآن الكريم و حتى

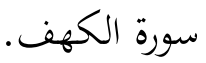
تم واصلت الباحثات من جامعة الملك عبدالعزيز بجدة بالعمل بالمشروع. مسنهج البحـث : اتبعـت في هـذا البحـث المـنهج التحليلي الاستقرائي الاسـتنباطي وملامح هذا العمل وخطواته أبينها على النحو التالي :

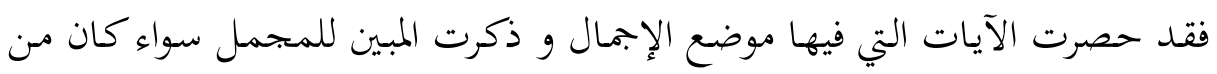

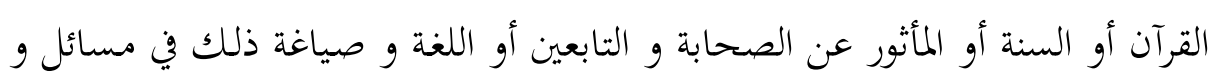
ترتيبها على النسق العلمي و ذلك بذكر الآية مرتبة على ترتيب المصحف ثم تخصيص ونس

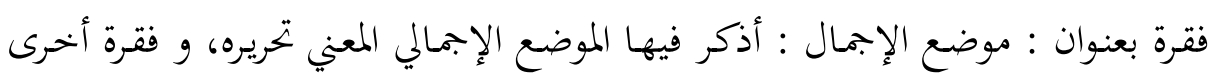

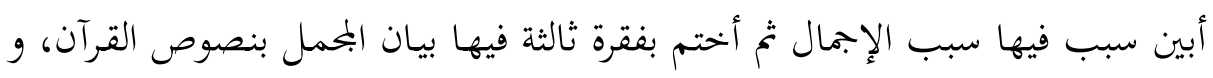

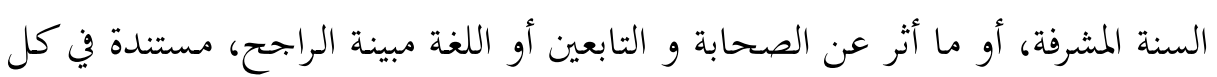
ذلك على أراء الأئمة المعتبرين، مع التعليق على ما يمتاج منها إلى تعليق. 
وقد وثقت الآيات والأحاديث والنقول عامة وفق قواعد البحث العلمي المعمول بها. خطة البحـث : اشتملت خطة البحثث على مقدمة، ومبحثين، و خاتمة، و قائمـة

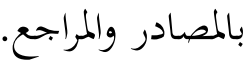

المقدمــة و تحتـوي على الآتي : أهميـة الموضـوع و وأسـباب اختيـاره،ومـشكلة البحـثـ وحدوده، وأهداف البحث، و الدراسات السابقة، و منهج البحث المتبع وخطته. المبحث الأول : البحمل والمبين عند اللغويين والمفسرين.

المطلب الأول : تعريف المحمل عند اللغويين والمفسرين. المطلب الثاني : تعريف المبين عند اللغويين والمفسرين. المبحث الثاني : الدراسة التطبيقية على سورة الفتح.

وقد قسمته إلى اثنتي عشرة مسألة، أفردت كل آية ورد فيها بحمل يحتاج إلى بيان بمسألة عنونتها بالآية التي ورد بها اللفظ البحمل. الخاتمة : و فيها أبرز النتائج والتوصيات.

والله تعالى أسأل أن يجعله عملب هذا خالصا لوجهه الكريم،

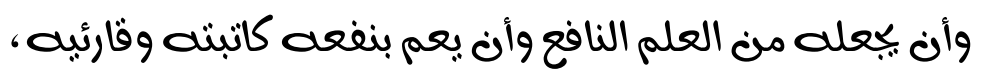
وأن برزفنا السداد في القول والعمله

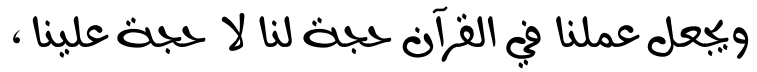
وهو وحده المسنعان وعلبه النكلان. 
المبحث الأول : المجمل والمبين عند اللغويين والمفسرين.

المطلب الأول : تعريف المجمل عند اللغويين والمفسرين.

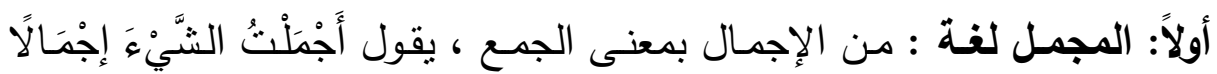

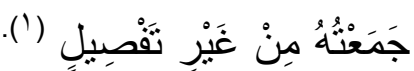

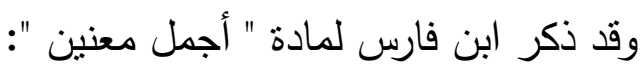

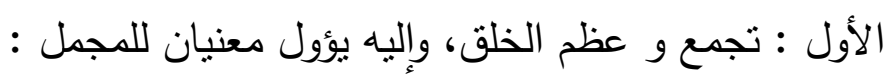

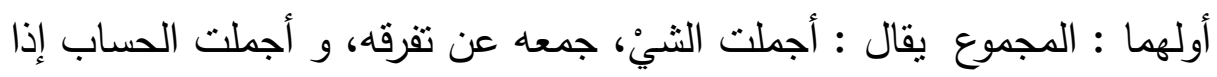

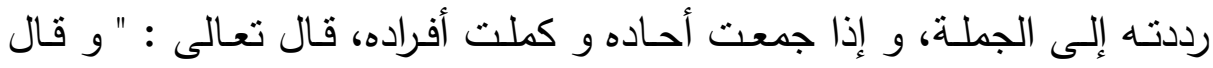

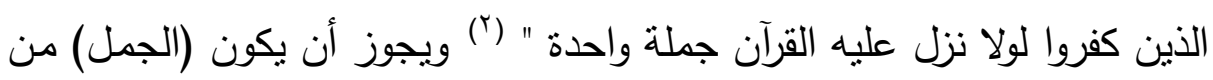

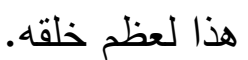

ثانيهما : المتحصل، قال ابن فارس : و أجملت الثنيْ إذا حصلته (ب).

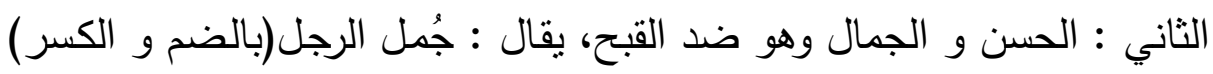

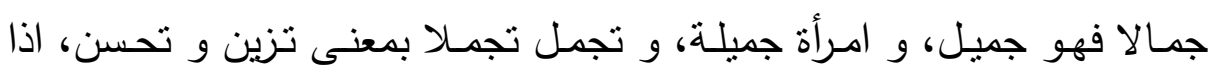

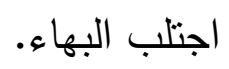
قال ابن قتيبة : أصله من الجميل : وهو ودك الثحم الدذاب يرا أن ماء السمن

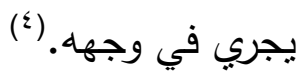

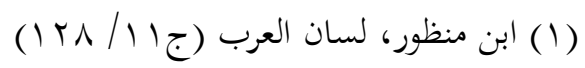

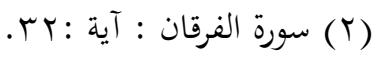

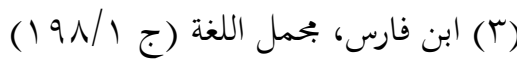

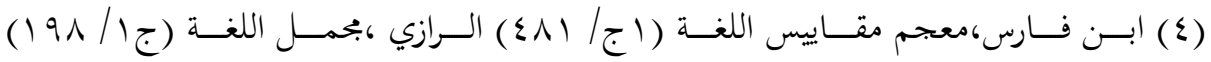

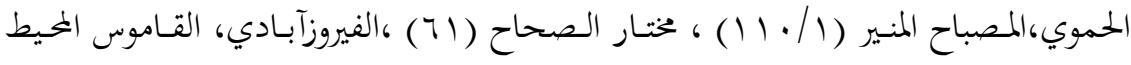

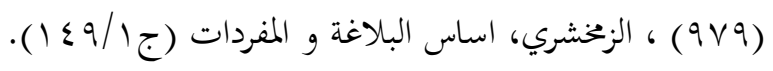




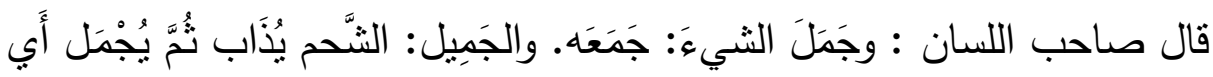

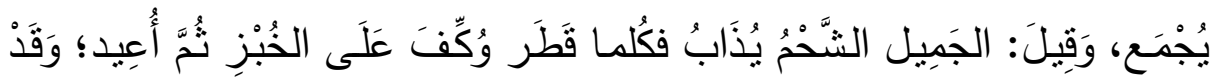

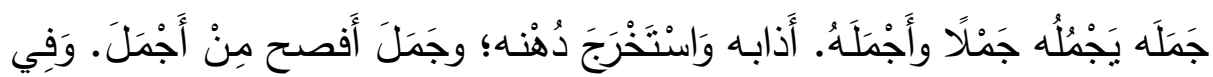

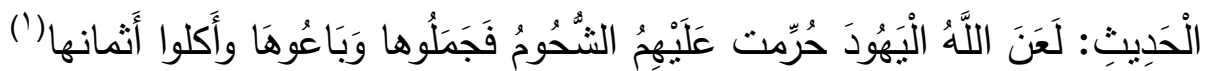

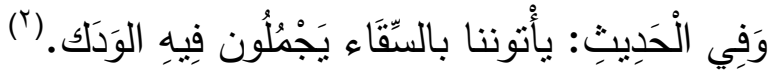

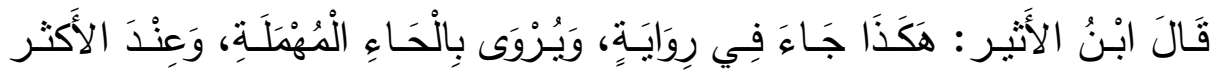
يَجْعَلُونَ فِيهِ الْوَدَكَكَ.

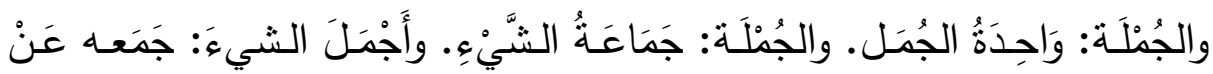

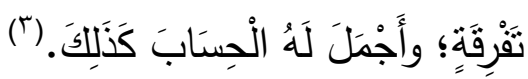

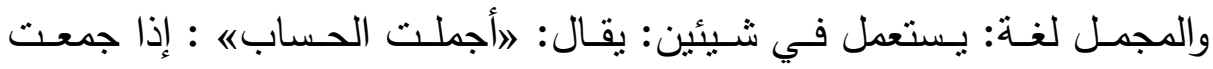
الحساب المتفرق، وعلى هذا يجوز إطلاق اسم المجمل على العام، لأنه يتتاول جملة من المسميات، والمجمل: المحصل، ويستعمل في الإبهام والإخفاء، يقال: ״فلان أجمل الأمر علىّه : أي أبهم (๕).

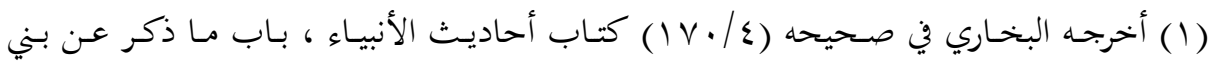

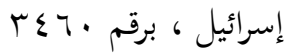

(T) أخرجه مسلم في صحيحه (TVN/I (TVN) كتاب الحيض ، باب طهارة جلود الميتة بالدباغ ، برقم (T) 1.7

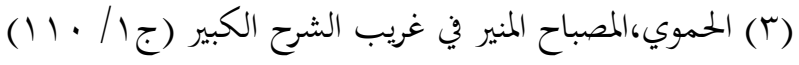

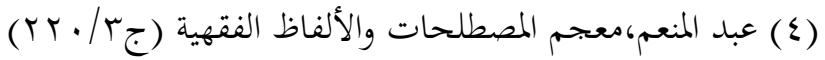


أما حقيقة المجمل فهو المشنتل على جملة أثياء كثيرة غير ملخصة (1)

\section{ثنانياً : تعريف المجمل اصطلاحا :}

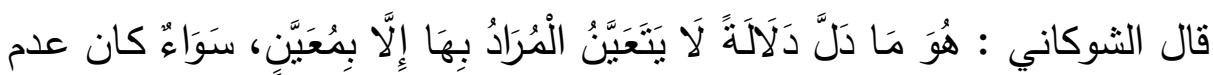

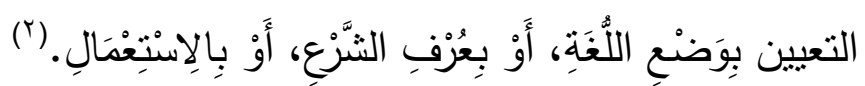

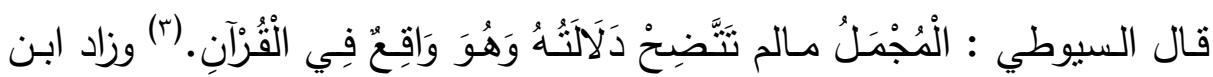
عقيلة قولـه : المجمل هو :مـا ازدحمت فيـه المعـاني ولم يعلم المـراد منـه إلا

باستقسار وتأمل (₹).

قال البلقيني : و مرادنا بالمجمل : ما وقع مجملا في الكتاب ثم بينته السنة (o) قال ابن الحصّار : من الناس من جعل المجمل والمحتمل بإزاء شيء واحد. والصواب أن المجمل المبهم الذي لا يُفهم المراد منه.

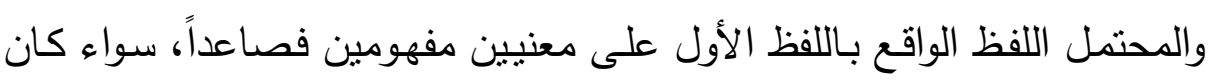
حقيقة في كلها أو في بعضها. فالفرق بينهما أن المجمل يدل على أمور معروفة، واللفظ مشترك متردد بينها (ج) بعها.

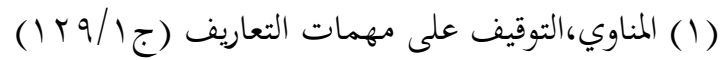

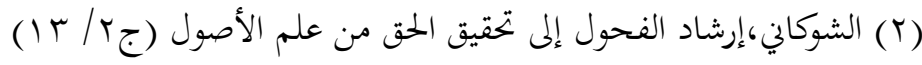

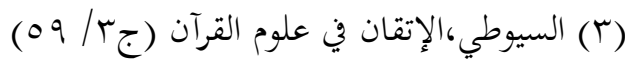

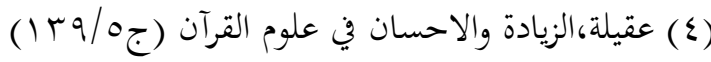

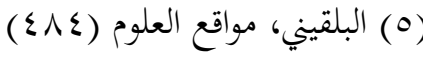

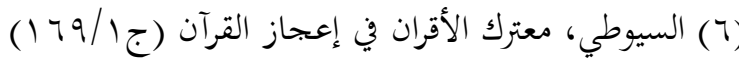


ويعرف ابن قاسم المجمل بأنه : ما لم تتضح دلالته فإنه منشابه نحو روَاللَّيَلِ إِذَا عَسْعَسَ. (') وهو بذللك يوافق السيوطي في عدم تعيين دلالة اللفظ ويمتاز بكونـه عد الإجمال شكلاً من أشنكال التشابه. وخلاصة القول أن المجمل هو اللفظ أو الفعل الذي تردد بين معتلمين أو أكثر

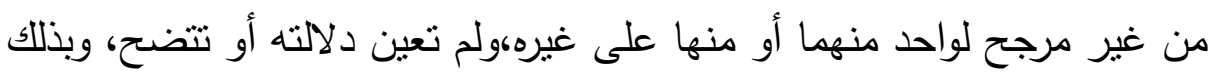

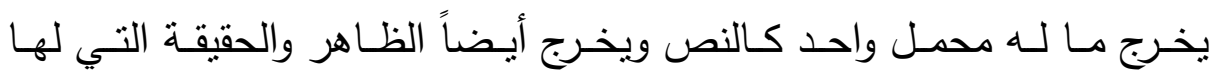
مجاز ،وبهذا يشمل المجمل القول والفعل والمشترك والمتواطئ.(؟) وإذا كان أحد

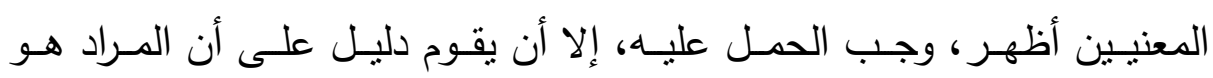

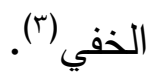

والمجمل بحسب مـا تقدم يفتح باب التأويل والسعة في المعنى والتدبر للنص

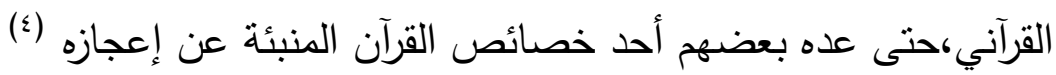

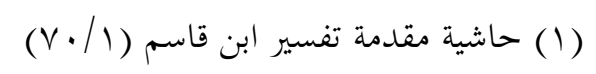

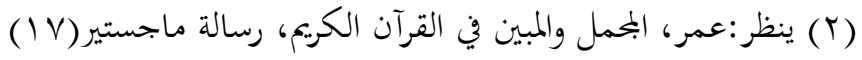

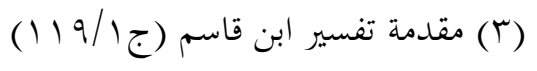

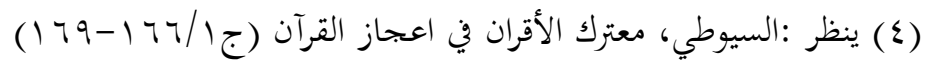


المطلب الثاني : تعريف المبين عند اللغويين والمفسرين.

\section{أولاً: تعريف المبين عند اللغويين:}

البيان :هو الوضوح و الظهور ، قال صاحب اللسان : والبيان : ما بين الثيْ

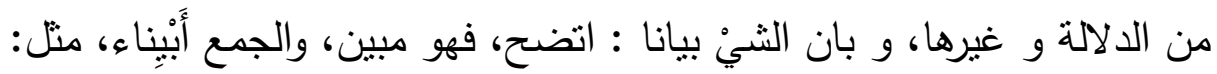

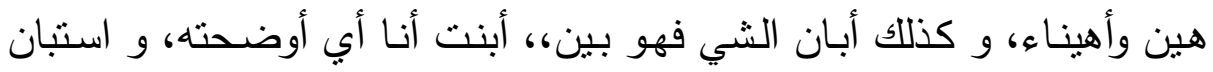
الثيء: اءهر واستبنته.

وفي الكليات أن البيان: في الأصل مصدر (بان الثيء) بمعنى تبين وظهر ، أو

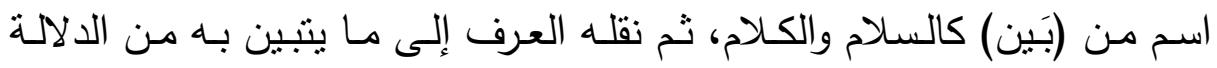

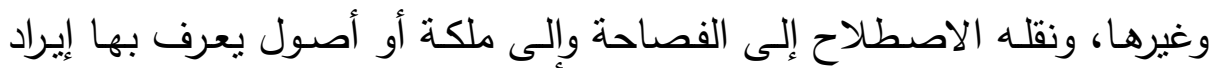
المعنى الواحد في صور مختلفة (')

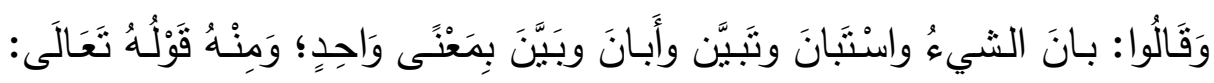

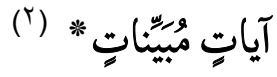

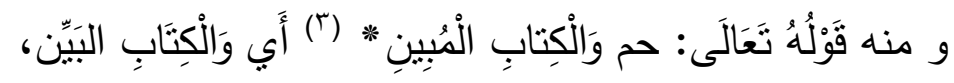
و قيل : معنى المبين الذي أبان طرق الهدى من طرق الضلالة، و أبان كل ما

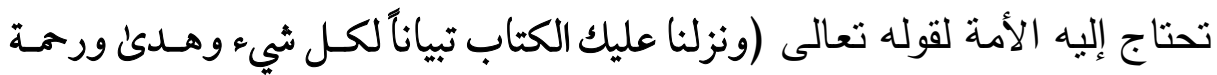

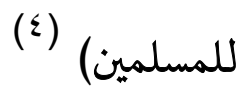

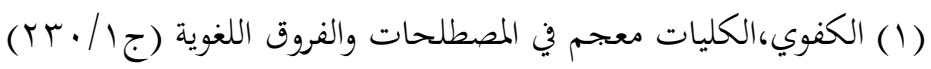

$$
\begin{aligned}
& \text { r : سورة النور (T) }
\end{aligned}
$$

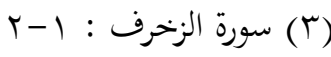

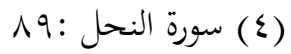




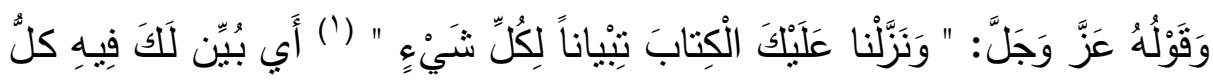

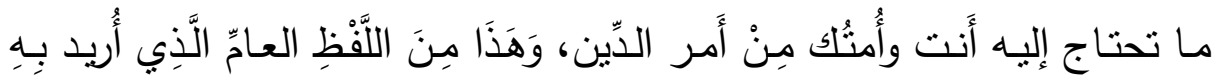
الخاصٌُ،

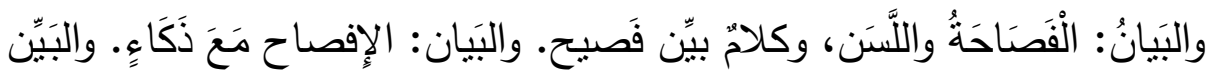

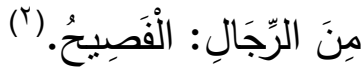

قـال الراغـب الاصـفهاني : و البيـان الكشف عـن الـشيء و هـو أعـم مـن النطق.....، و سمي الكلام بيانا لكشفه عن المعنى المقصود إظهاره نحو قوله

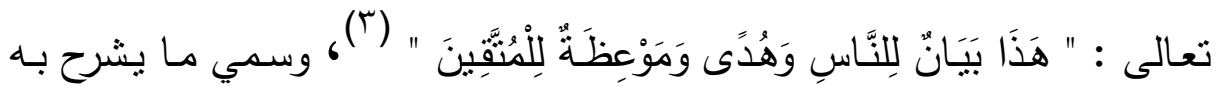

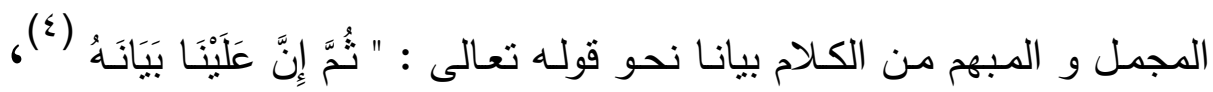

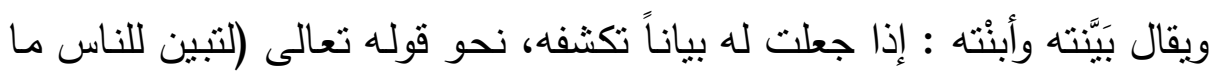

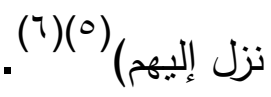
وفرَّق أبو البقاء الكفوي بين البيان والتبيان بقولهـ : (والبيان مـا يتعلق باللفظ،

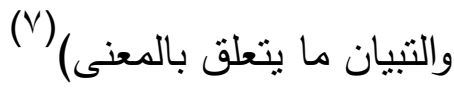

$$
\begin{aligned}
& \text { (1) سورة النمل } 19
\end{aligned}
$$

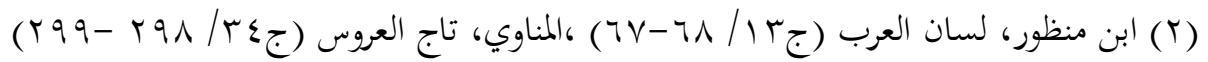

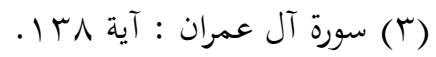

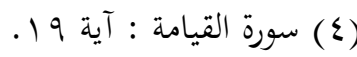

$$
\begin{aligned}
& \text { (0) سورة النحل : آية عـ آهوره }
\end{aligned}
$$

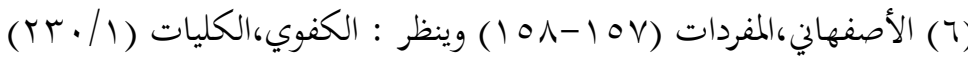

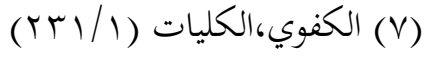


ثانياً : تعريف المبين اصطلاحا:

يعرف السيوطي المبين بقوله : هو الواضح بنفسه أو بغيره (') والمبيّن هو : ما يفرّق بين الثيء وما يشاكله، فهو دلالة على المعنى المراد على

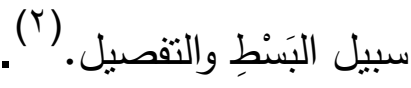
و قيل : المبين هو الدال على المراد بخطاب لا يستقل بنفسه في الدلالة عليه، و قد جاء البيان في القرآن الكريم على عدة وجوه تعبد الله بها عباده بينها الإمام

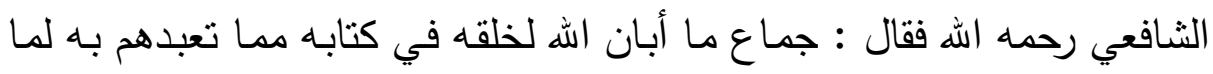
مضى في حكمه جلى ثناؤه من وجوه : فمنها مـا أبانـه لخلقه نـصا مثل حمل فرائضه في أن عليهم صـلاة وزكـاة و

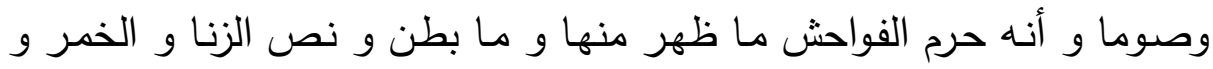

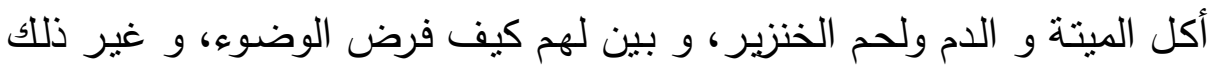

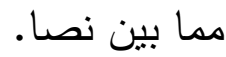

و منه ما أحكم فرضه في كتابه و بين كيف هو على لسان نبيه صلى الله عليه وسلم ، مثل عدد الصلاة، و الزكاة و وقتها و غير ذللك من فرائضه التي أنزل

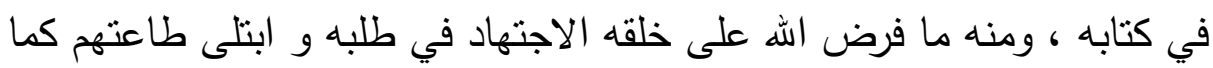

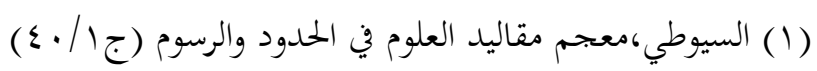

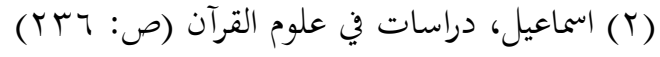


ابتلى طاعتهم في غيره مما فرض عليهم، فإنه يقول تبارك وتعالى : " وَلَنَبُْوَنَكُمْ

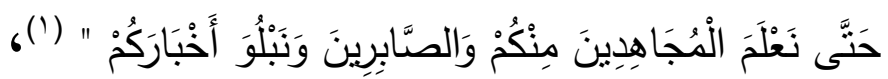

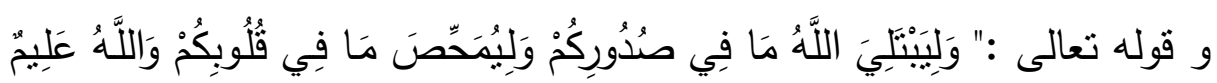

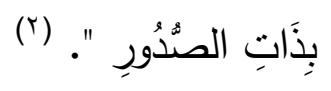

هذا وقد عَدَّ الفيروزآبادي لفظة المبين من أسماء القرآن الكريم لقوله تعالى (قرآن

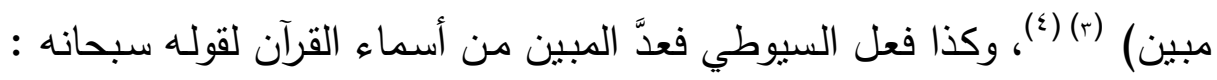

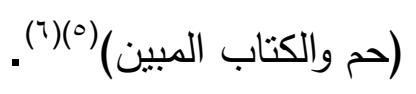

وذكر أبو البقاء للبيان أنواعاً منها : بيان الضرورة وبيان التقرير، وبيان التبديل،

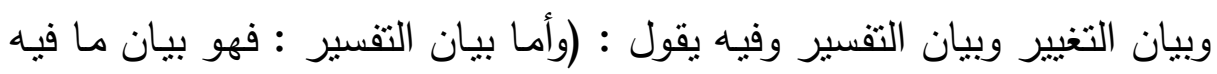

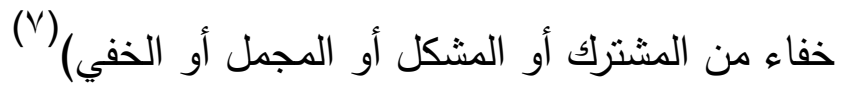

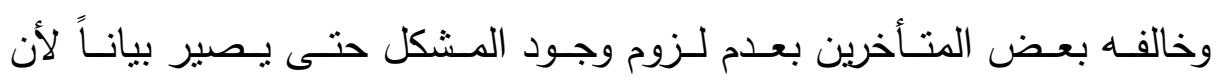
النصوص الثرعية التي أوردت الأحكام ابتداء تنمى بيانا قال تعالى: (هذا بيان

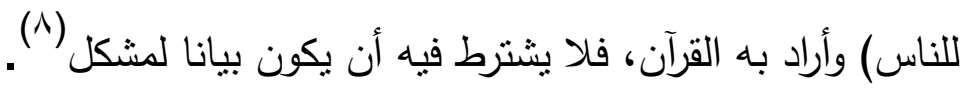

$$
\begin{aligned}
& \text { (1) سورة محمد : آية آ. }
\end{aligned}
$$

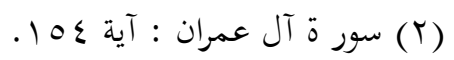

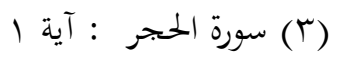

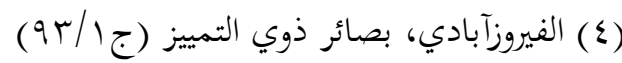

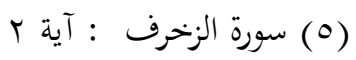

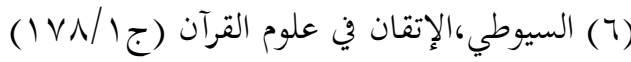

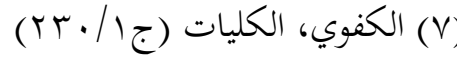

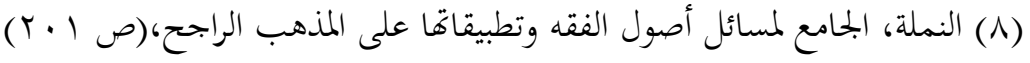




\section{المبحث الثاني : المجمل ِِّْ سورة الفتح وبيانه :}

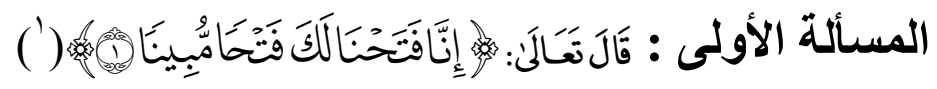

$$
\text { موضع الإجمال في قوله نعالى : " فتحا" }
$$

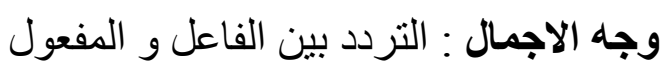

اختلف في هذا الفتح ما هو ؟و و في المر اد بالفتح أربعة أقو ال : أحدها : أنه كان يوم الحدييية، قاله الأكثرون.

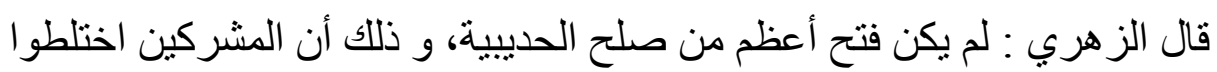

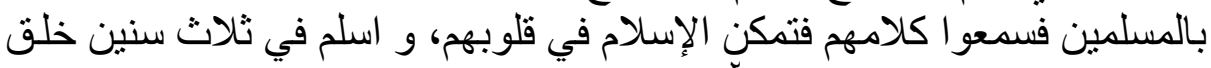
كثير و كثر بهم سو اد الإسلام (").

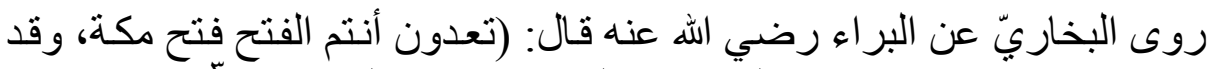

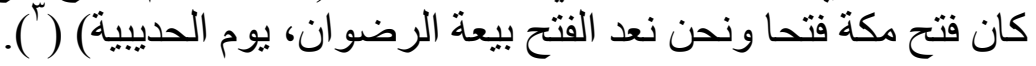

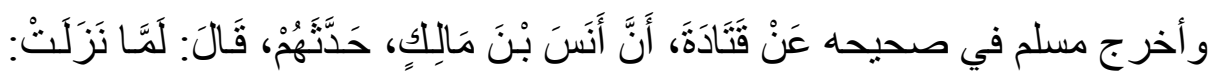

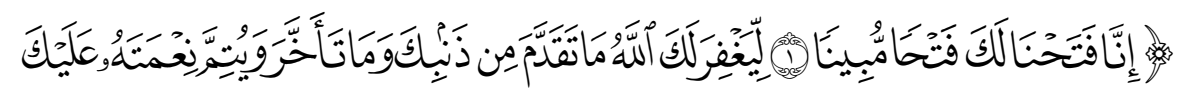

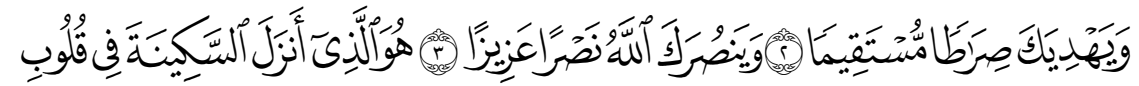

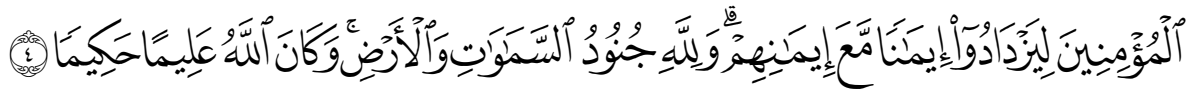

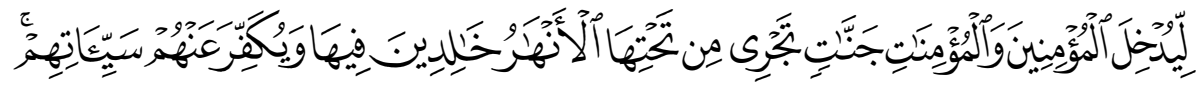

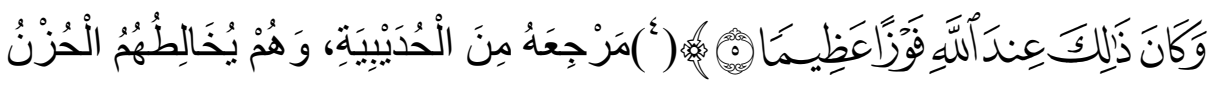

$$
\begin{aligned}
& \text { (1) سورة الفتح : آية } 1 \text { (1) }
\end{aligned}
$$

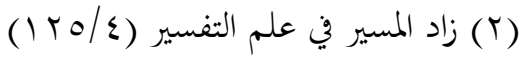

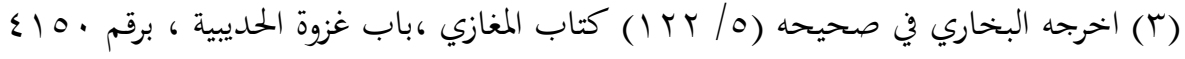

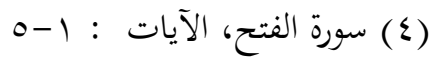




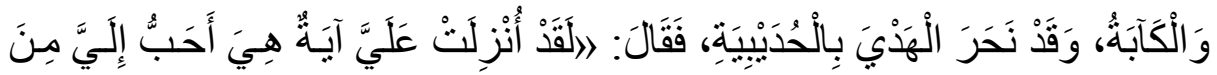

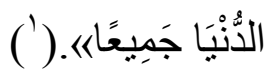

قال ابن كثير في تفسيره : فقوله: إِنَّا فَتَحْنا لَكَكَ فَتْحَاً مُبِيناً أي: بينا ظـاهر او المر اد

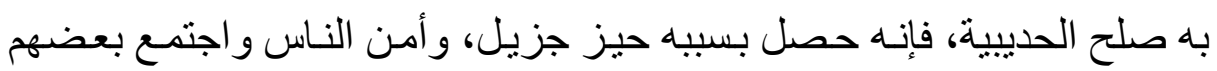

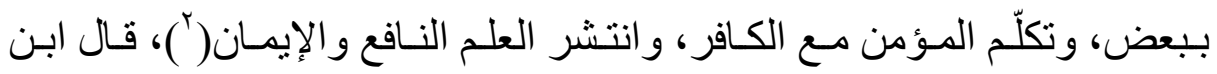

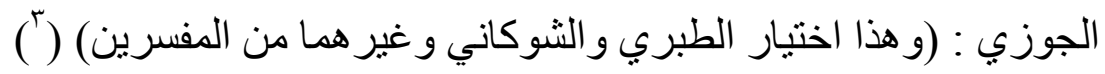
وبما تقام من مؤيدات فإن هذا القول بيِّن الرجحان ومستحق للوصف بأنها (فتح

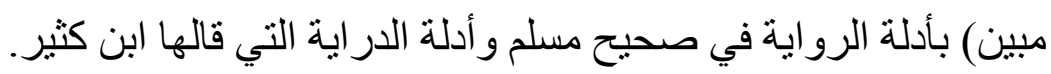

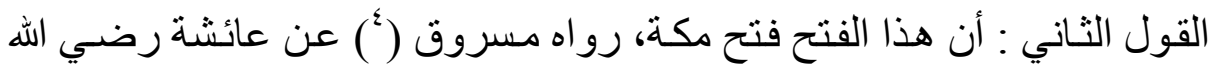

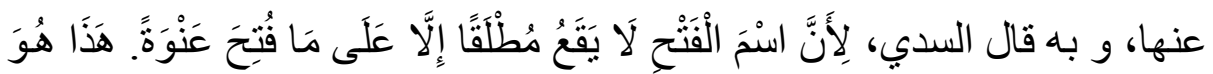

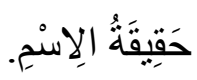

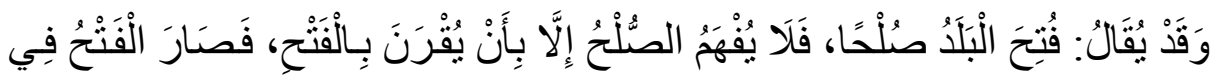

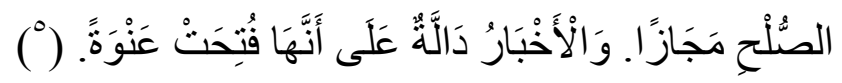
و قال بعض مَن ذَهَب إِلى هذا: إِنما وُعِد بفتح مكة بهذه الآية.

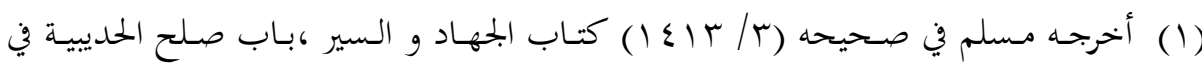

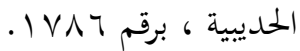

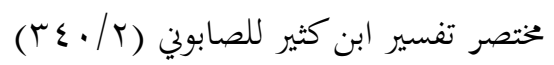

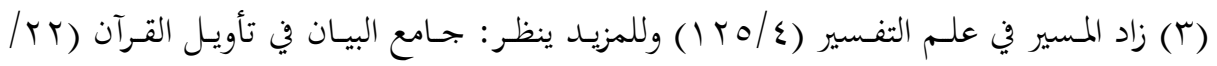

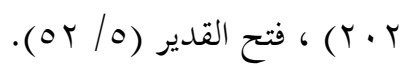

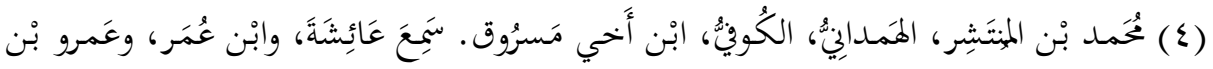

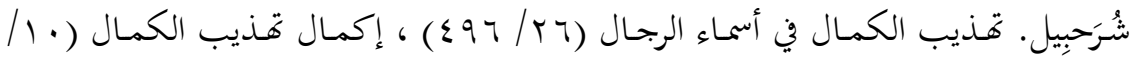




$$
\text { الثالث: أنه فتح خيبر ، قاله مجاهد، و العوفي. }
$$

رابع: أنه القضاء له بالإسـام، قالـه مقاتل. وقال غيره: حَكَمْنـا للك بإظهار دِينك

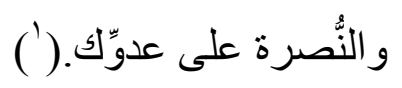

و عليه فالر اجح هو القول الأول لما تقدم من أدلة تتقوى باللغـة ايضاً: و الفتح قد

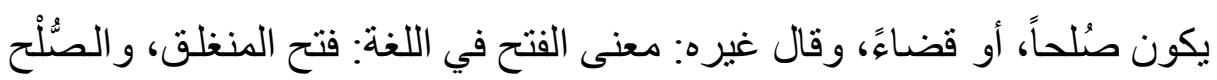

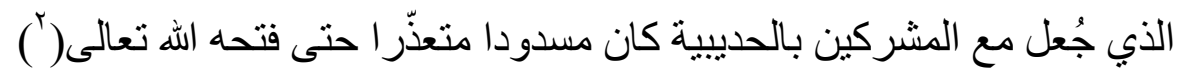

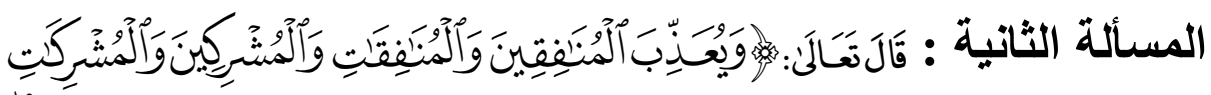

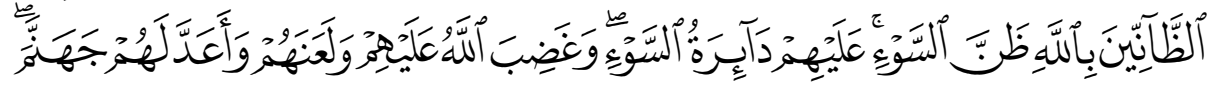

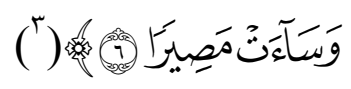

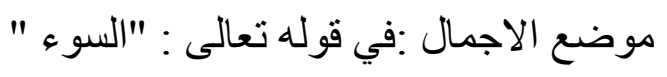

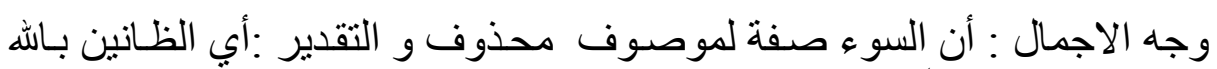

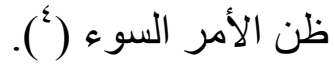
التوجيه و البيان : و هذا الظن يحتمل وجوها : أحدها : هو الظن الذي ذكره الله

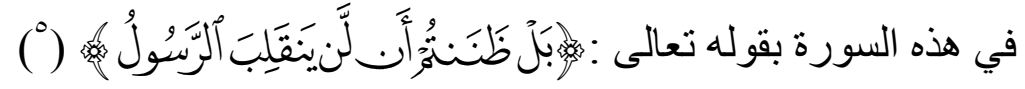

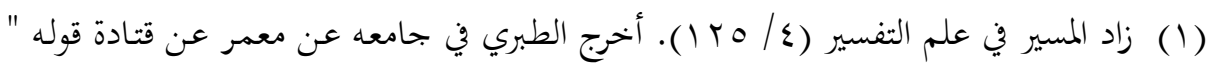

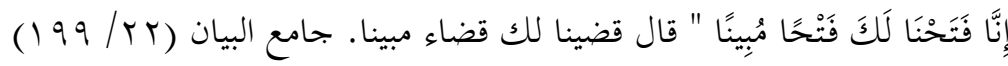

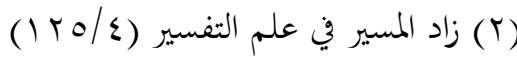

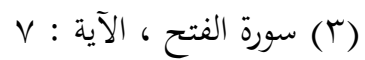

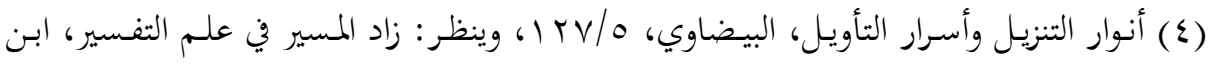

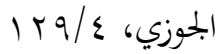

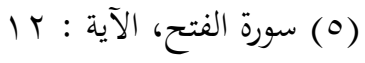




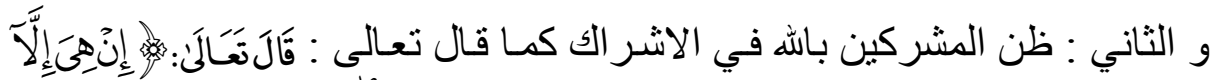

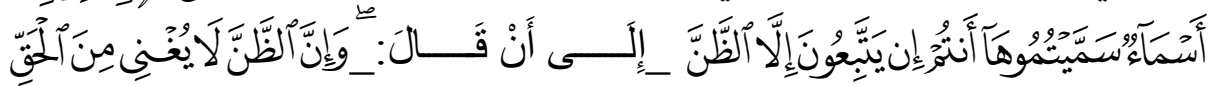

(') شَيْنَ

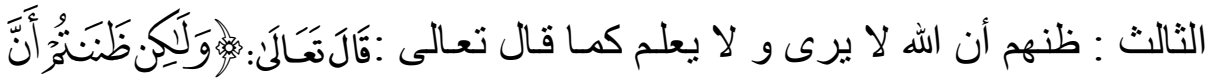

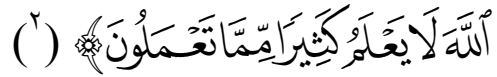

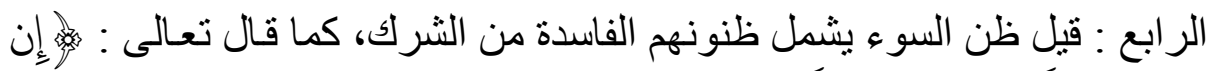

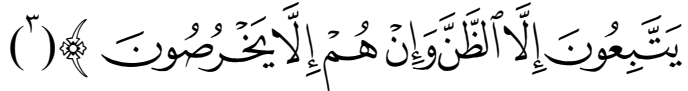

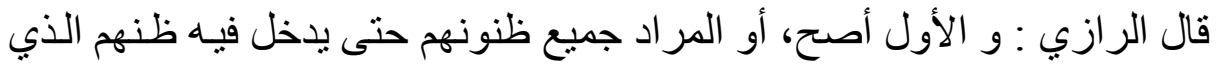

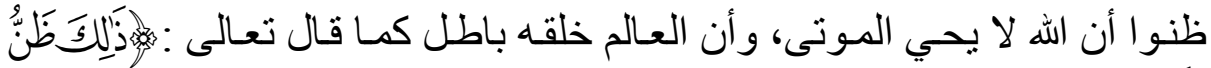

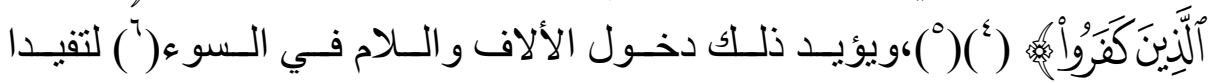
الاستغراق لأنو اع الظنون ومداخله.

و الحق أن الفظ السوء لفظ جـامع لأشـكال الفساد لذا فإن مـا تقدم مـن أقوال

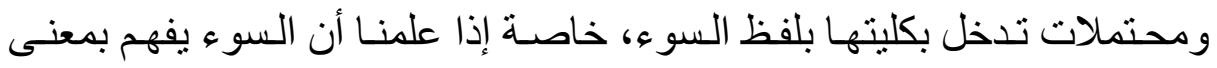

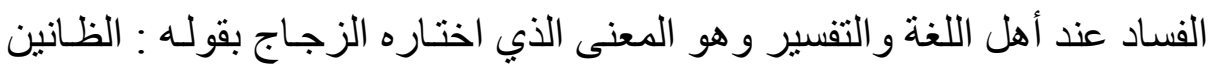

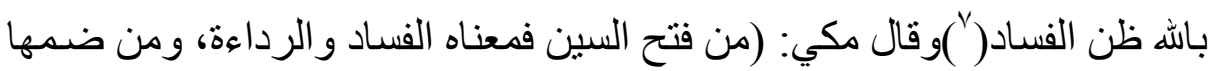

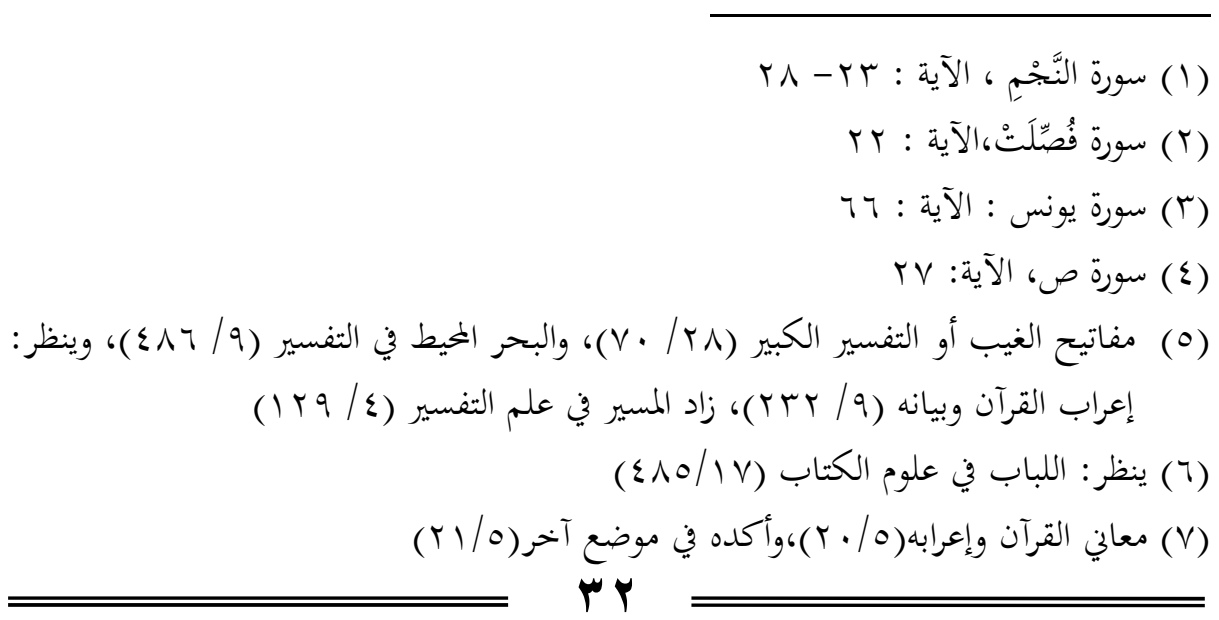




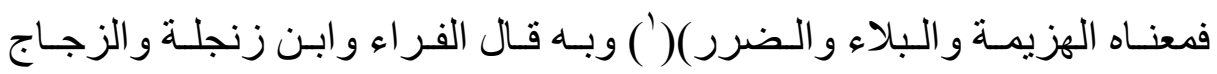

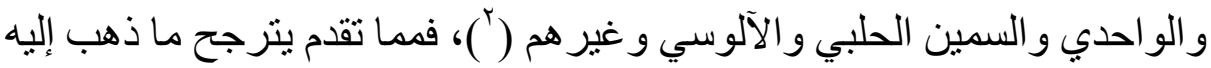

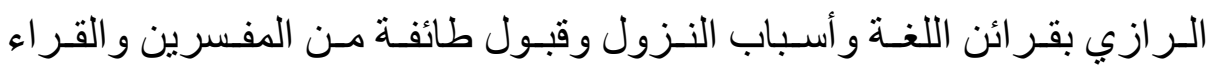
و اللغويين له.

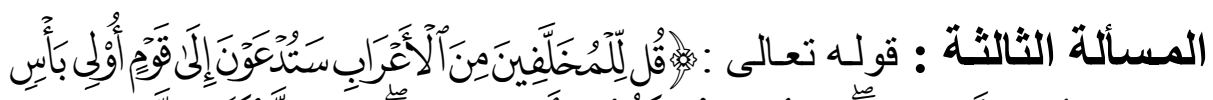

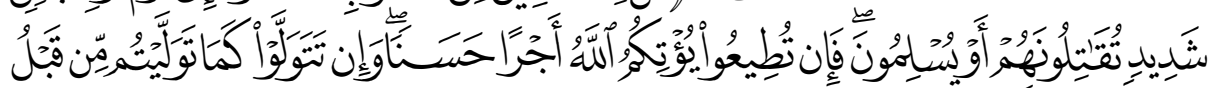
(")

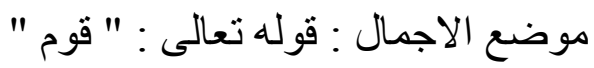
وجه الاجمال : إلى قوم متعلقان بتدعون، و اختلف العلماء في المشار إليهم : قال القاسمي رحمه الهه : و مثار الخلاف هو عموم ظاهر الآية و شمول مصداقها

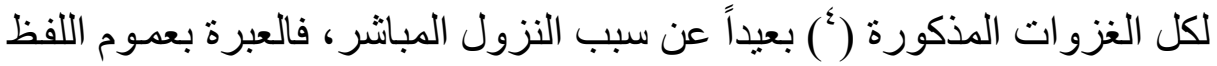

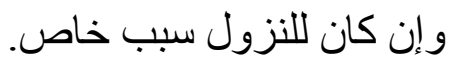

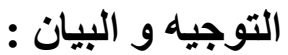

اختلف أهل التأويل في هؤلاء الذين أخبر الله عز وجل عنهم أن المخلفين من

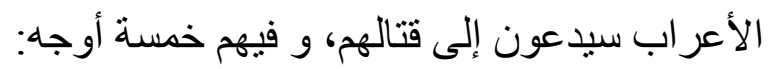

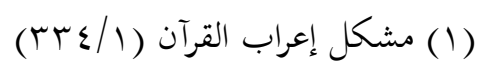

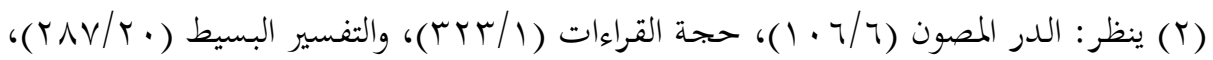

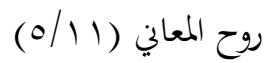

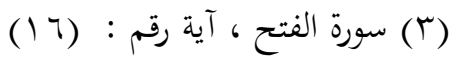

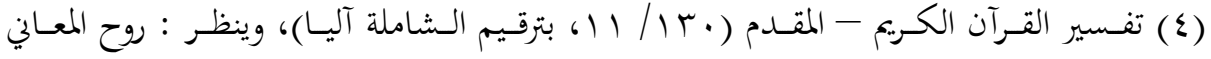

$$
\text { (1. (1/ץ \) }
$$


أحدها: أنهم أهل فارس، قاله ابن عباس.

الثاني: الروم، قاله الحسن و عبد الرحمن بن أبي ليلى.

الثالث: هو ازن و غطفان بحنين، قاله سعيد بن جبير وقتادة.

الر ابع: بنو حنيفة مع مسيلمة الكذاب، قاله الزهري.

الخامس: أنهم قوم لم يأتو ا بعد، قاله أبو هريرة.(')

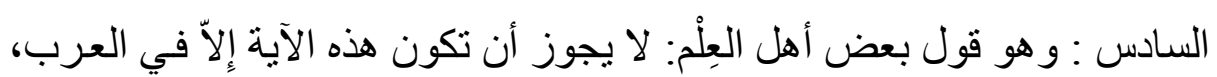

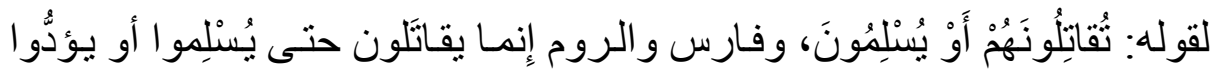

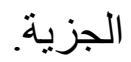

وقد استدلَّ جماعةٌ من العلماء على صِحَّة إِمامة أبي بكر وعمر بهذه الآيـة، لأنهـ

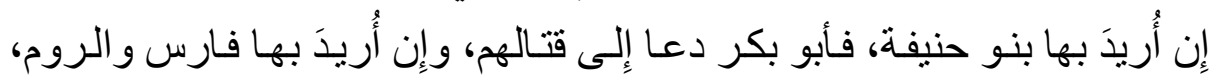

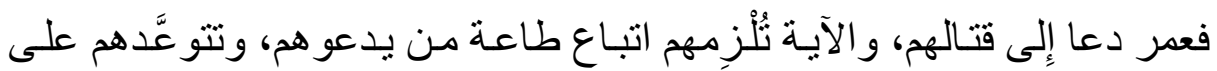

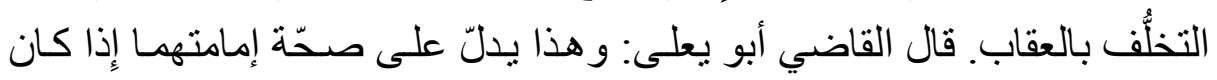

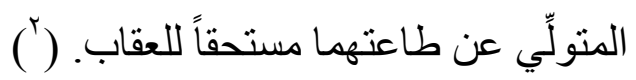

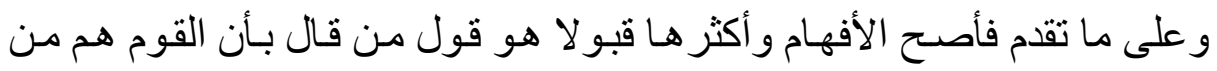

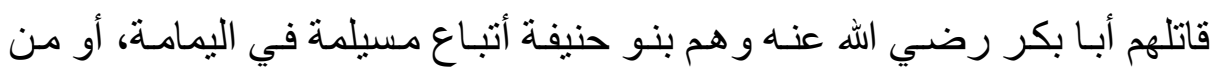

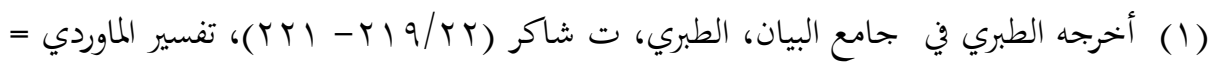

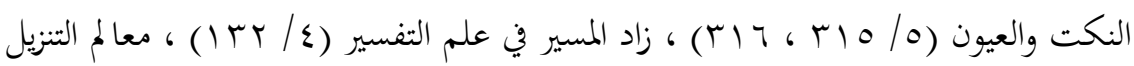
- طيبة (V/Y)

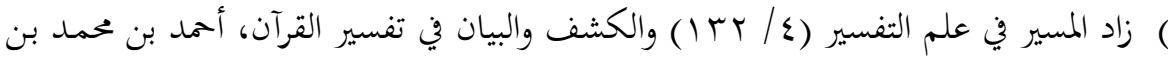

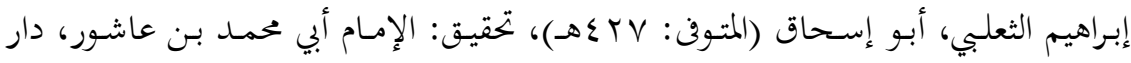

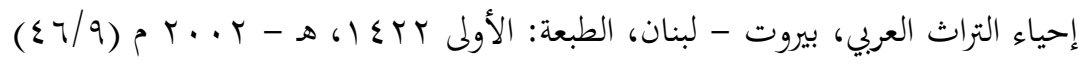


قاتلهم أمير المؤمنين عمر بن الخطاب رضي الله عنهـه وهم فـارس والروم، وهو

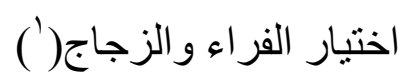

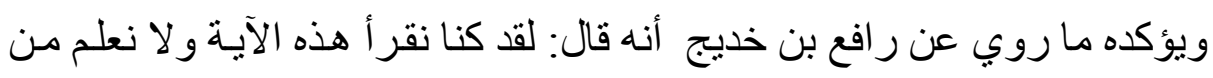

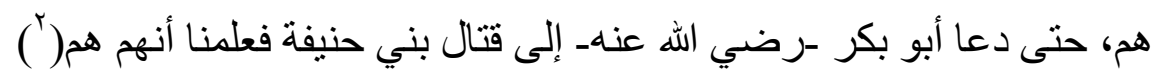

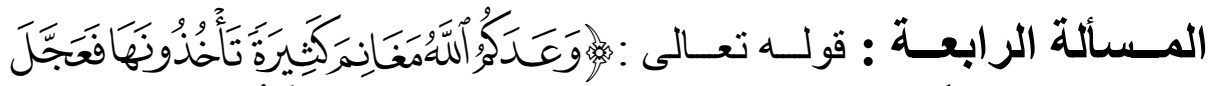

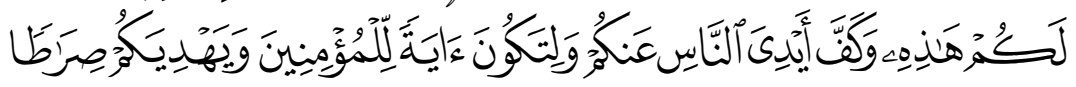

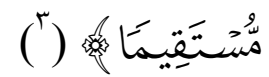

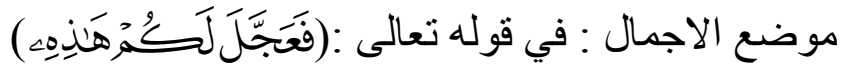
وجه الاجمال : التعدد و الاحتمال في مرجع الإشارة، فالمعجلات في الدنيا عديدة

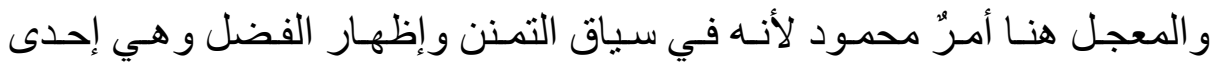

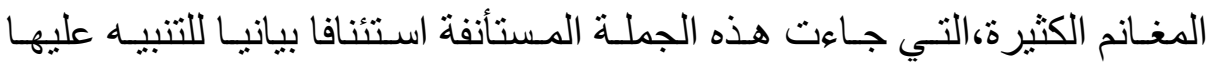
ولتخصيصها بمزيد عناية وكريم رعاية(").

التوجيه و البيان : إن المشار إليه في قوله تعالى : "هذه " يرجع إلى أمرين : الاول : الإثـارة بهذه إلى البيعـة و التخلص من أمر قريش بالصلح، قالـه ابن

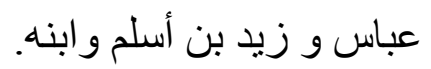
الثاني : مغانم خيبر ، قاله مجاهد و قتادة و الجمهور، و أختاره الطبري حيث قال

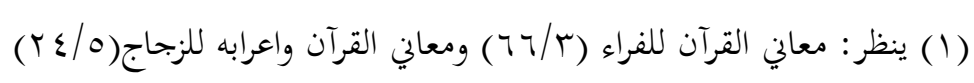

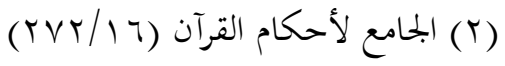

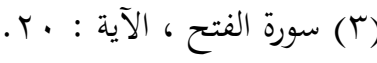

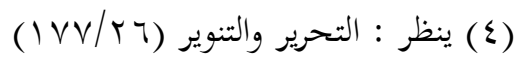

ro $\overline{=}$ 
وأولى الأقوال في تأويل ذللك بالصو اب مـا قالـه مجاهد، وهو أن الذي أنتابهم الله من مسير هم ذلك الك في

مع الفتح القريب المغانم الكثيرة من مغانم خيير ، وذللك أن المسلمين لم يغنمو ا بعد الحيبية

غنيمة، ولم يفتحوا فتحـا أقرب من بيعتهم رسول الله عليهولسلم بالحدييية إليها من

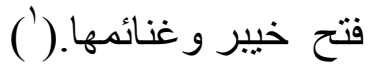
و هذا ما رجحه جمهور المفسرين (r) و بذلك يكون ما أجمل قد بان بهذا البيان.

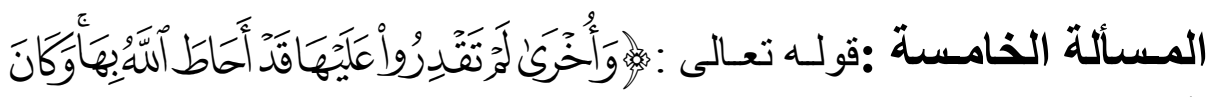

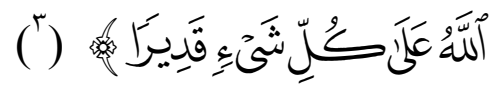

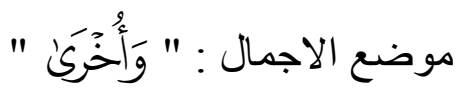

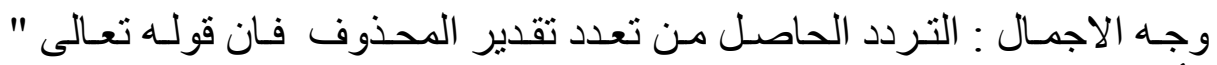

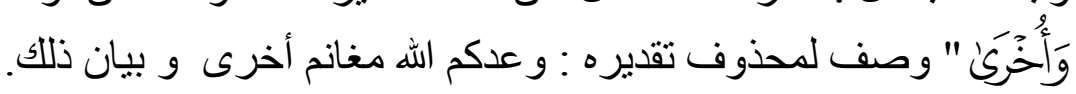
التوجيهه و البيان : المعنى: و عدكم الله مَغانمَ أُخرى وفيها أربعة أقو ال رئيسة

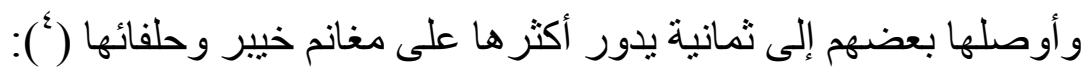
أحدها: أنها مـا فُتح للمسلمين بعد ذلك. روى سماك الحنفي عن ابن عبـاس:

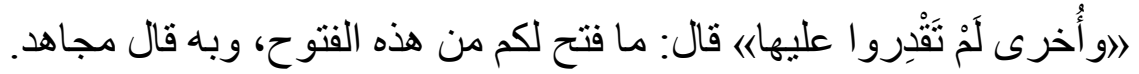

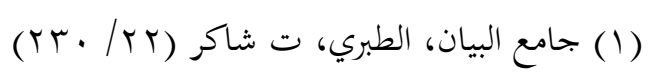

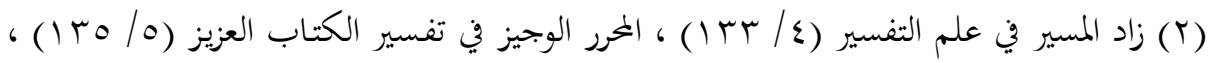

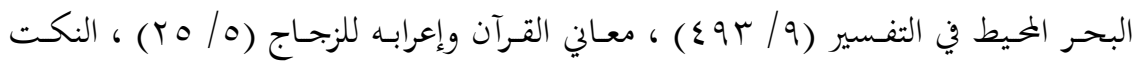

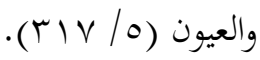
Y

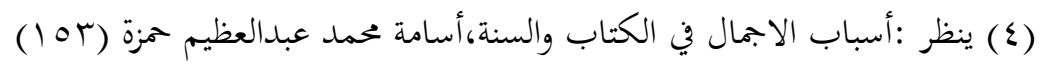


و الثاني: أنها خيير، رواه عطية، و الضحاك عن ابن عباس، وبه قال ابن زيد.

والثالث: فـارس و الرووم، روي عن ابن عبـاس أيضاً، وبـه قـال الحسن، و عبد الرحمن بن أبي ليلى. (- مارس

و الر ابع: مكة، ذكره قتادة، وابن قتيبة، قال ابن جرير : وهذا القول الذي قاله التها

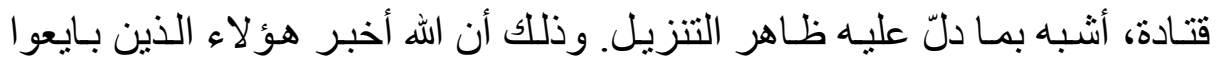

رسول الله عليلوسللم تحت الثجرة أنه محيط بقرية لم يقدروا عليها لتها ('). ومعقول أنه لا يقال لقوم، لم يقدروا على هذه المدينة، إلا أن يكونوا قد راموهـا

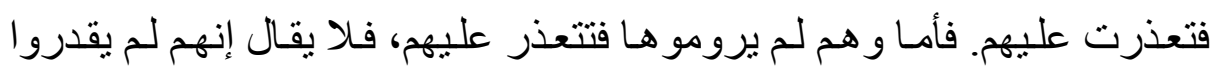
عليها. فإذا كان ذلك كذلك،

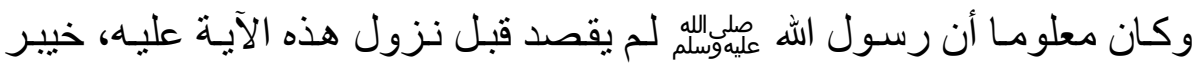

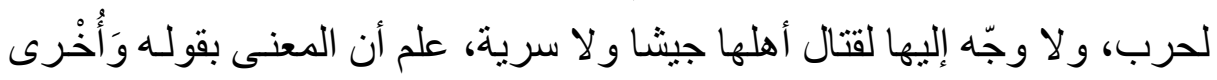

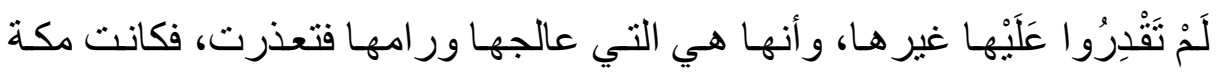

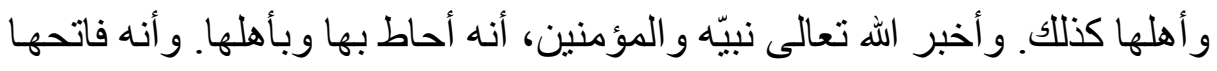

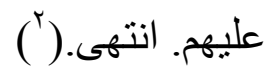

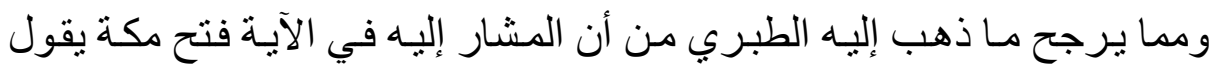

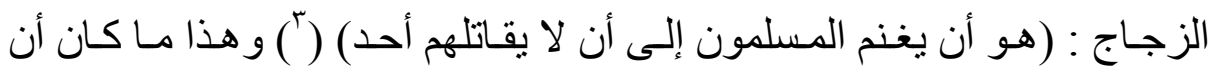

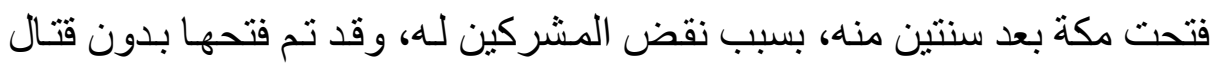

يذكر ()

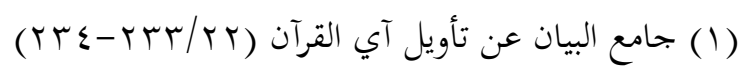

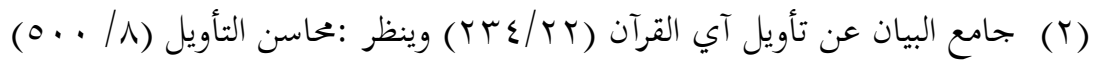

$$
\begin{aligned}
& \text { (Y) معاني القرآن واعرابه (Y/0) }
\end{aligned}
$$

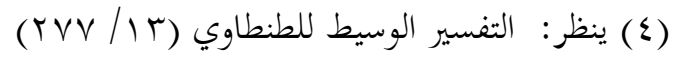




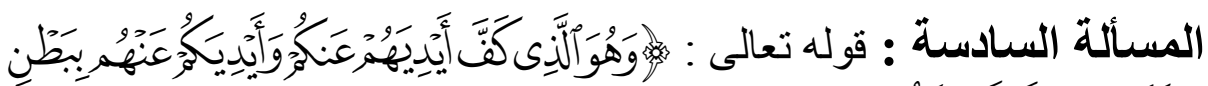

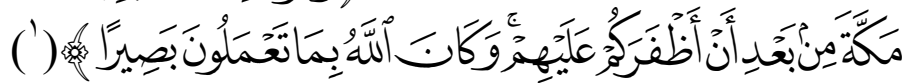

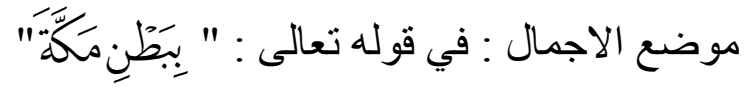

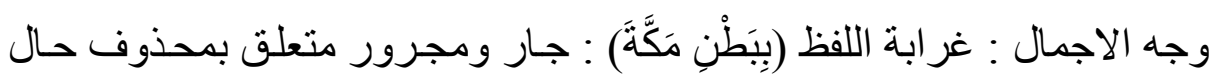

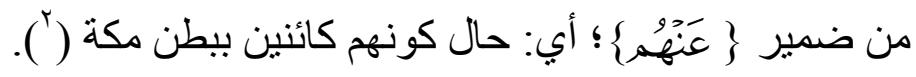

التوجيه و البيان : قال المفسرون: ومعنى الآية: إِن الله تعالى ذكر مِنَّته إذّ حجز بين الفريقين فلم يقتتلا حتى تم الصلح بينهم.

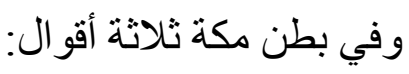

أحدها: أنه الحديبية،(قاله أنس. أخرج مسلم عن انس بن ماللك أن ثمانين رجلا من

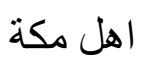

هبطو ا على رسول الله صلى الله عليه و سلم من جبل التنعيم متسلحين، يريدون غرة النبي

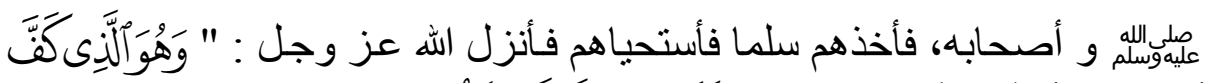

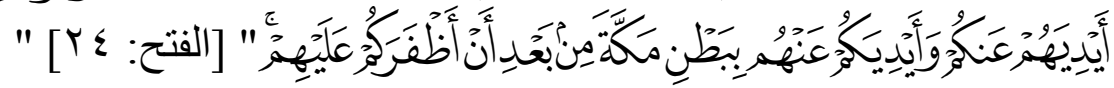

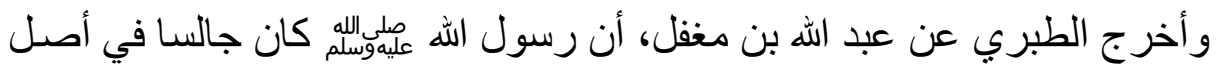

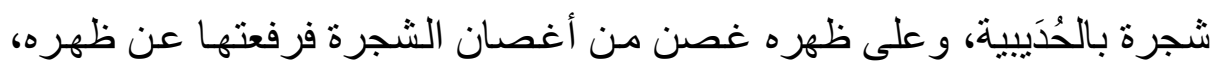

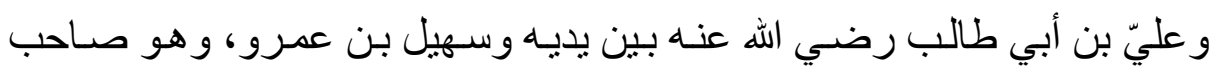

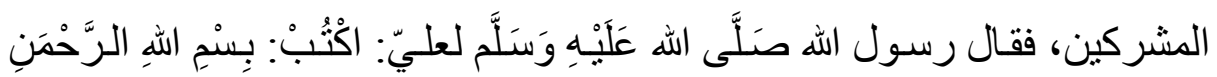

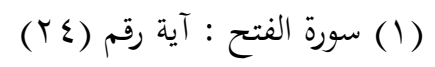

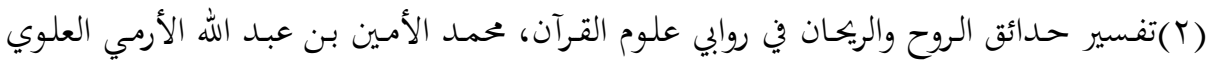

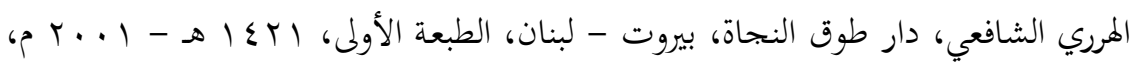

$($ (T)/ TV) 
الرَّحِيه، فأمسك سُهَيل بيده، فقال: ما نعرف الرحمن، اكتب في قضيتنا ما نعرف.

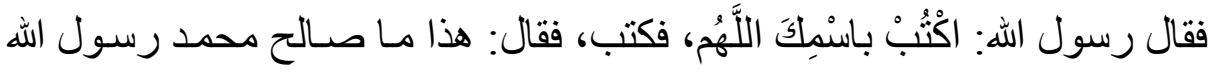

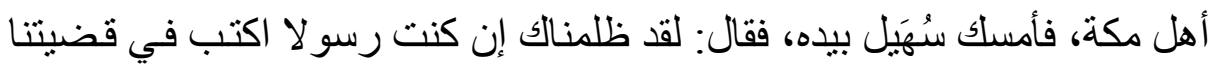

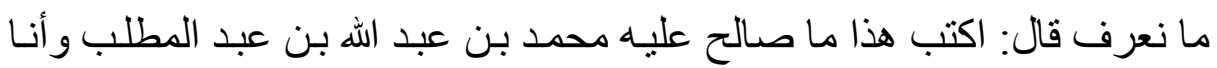

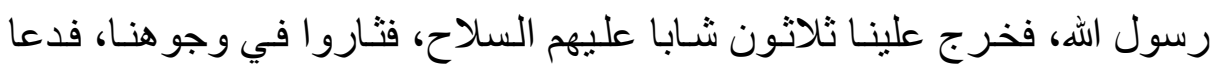

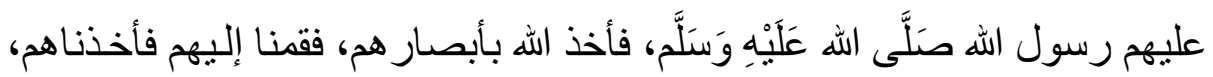

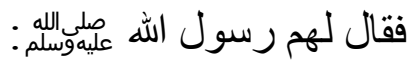

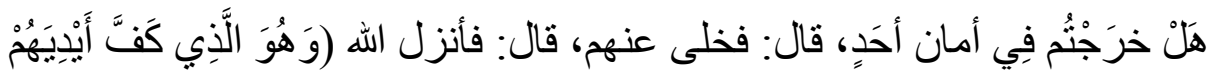

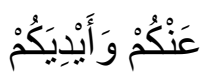

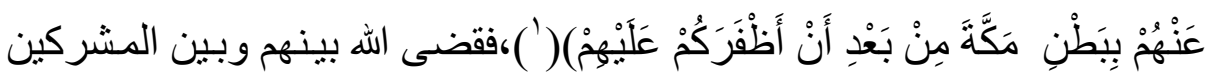

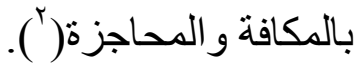
و الثاني: و ادي مكة، قاله السدي،و الثالث: التنعيج(") وقيل: مكة اسم للبلد، وبكة

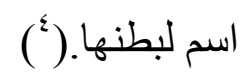
والذي أجدني أكثر قبو لا له ما وافق معنى البطن من الأماكن المتقدمة فهو الأولى

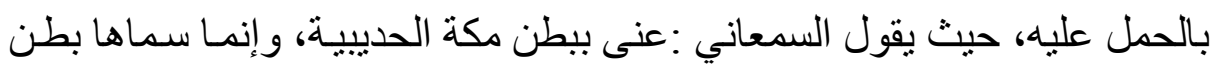

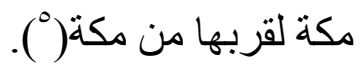

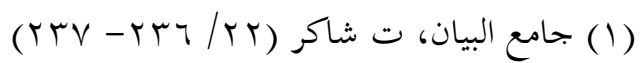

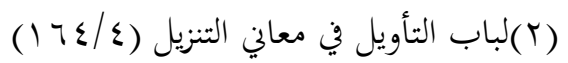

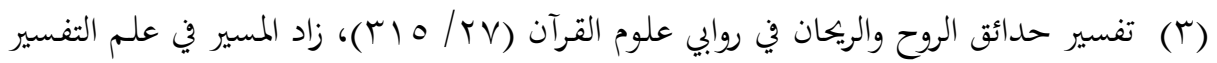

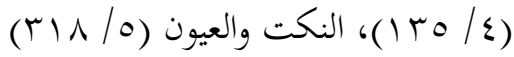

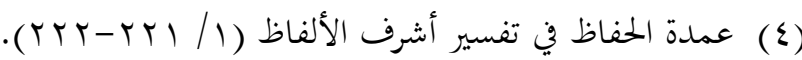

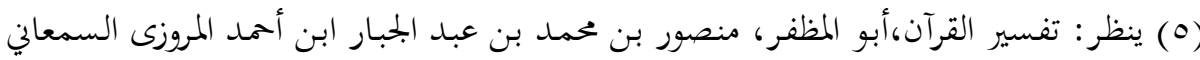

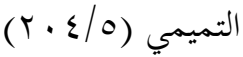


ويتفق مع هذه النتيجة ابن عاشور إذ يقول في توفيقه بين أقو ال المفسرين وسياق

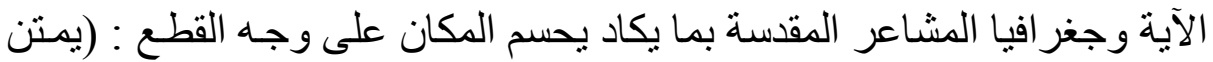

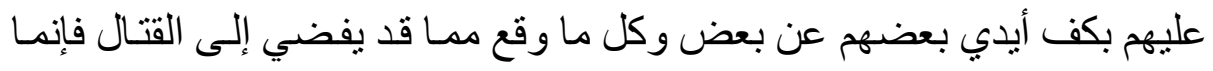

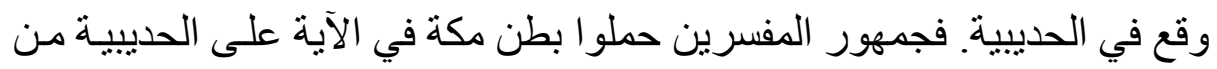

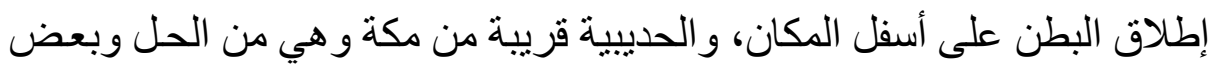

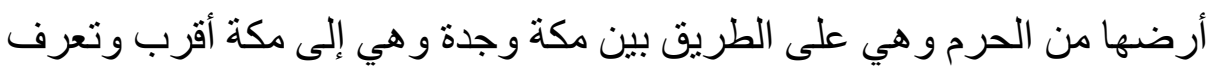

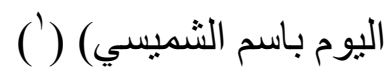

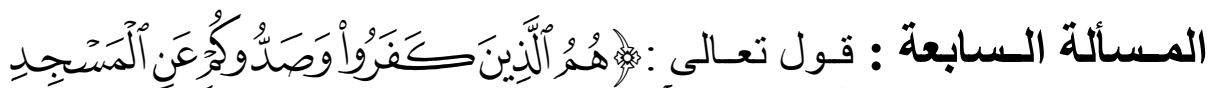

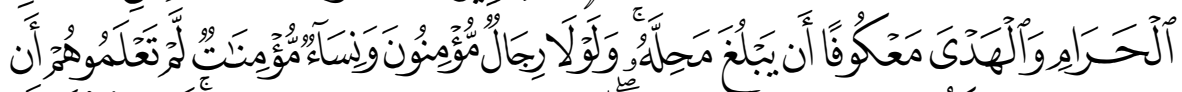

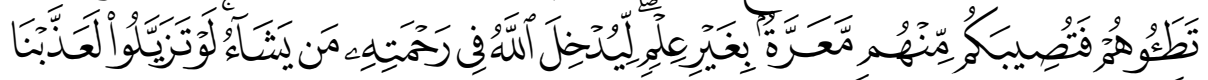

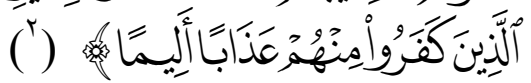

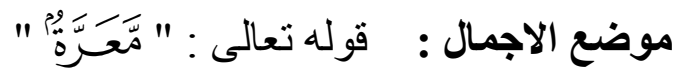
وجه الاجمال : غرابة اللفظ، فالمعرة : السوء و المكروه اللاصق، مـأخوذة من

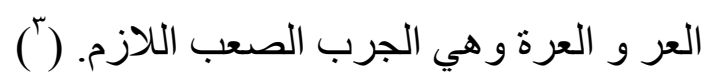
قال الهروي في التهذيب : المعرة التي صـان الله عز وجل المؤمنين عنها هي :

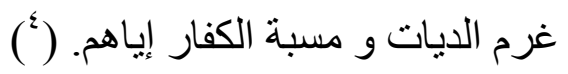
التوجيهه و البيـان : و معنسى الآيـة : يقول تعـالى ذكره: ولولا رجـال مـن أهل

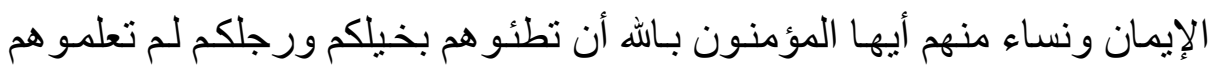

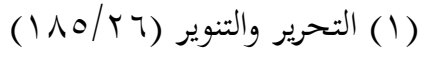

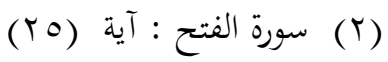

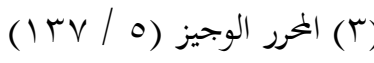

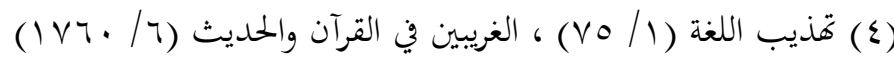


بمكة، وقد حبسهم المشركون بها عنكم، فلا يستطيعون من أجل ذلك الخروج إليكم فتقتلو هم.

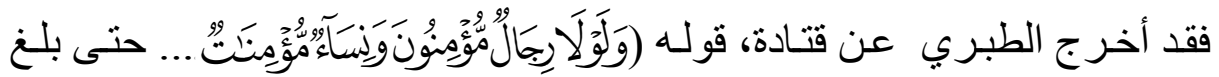

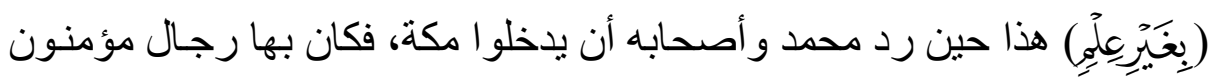

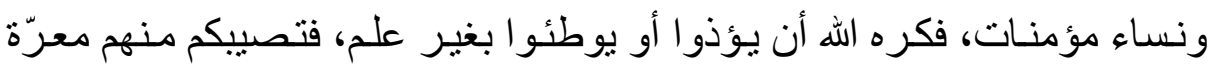

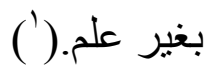

و اختلف أهل التأويل في المعرّة التي عناها الله في هذا الموضع، فقال ابن زيد : هي المأثث.

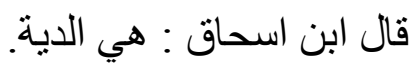

قال ابن عطية : و و هذان ضعيفان، لأنه لا إثم و لا ديـة في قتل مؤمن مستور

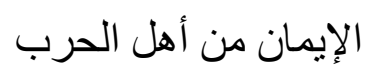

و قال القاضي منذر بن سعيد : المعرة : أن يعنفهم الكفار و يقولون قتلوا أهل دينهم. و قيل : هي الملامة و تألم النفس منه في باقي الزمن. قال الطبري : و المعنى فتصييكم من قبلهم معرة تعرون بها يلزمكم من أجلها

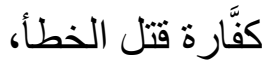
وذللك عتق رقبة مؤمنة، من أطاق ذلك، ومن لم يطق فصيام شهرين. و قال : و إنما اخترت هذا القول دون القول الذي قاله ابن إسحاق، لأن الله إنما أوجب على قاتل المؤمن في دار الحرب إذا لم يكن هاجر منها، ولم يكن قاتله علم المان التها

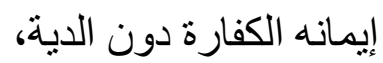




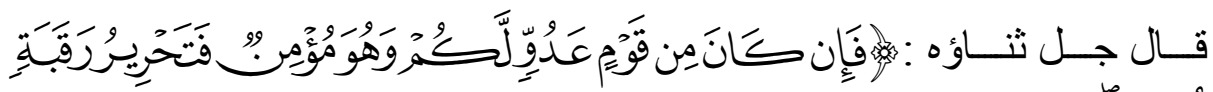

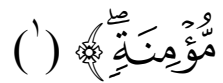

لم يوجب على قاتله خطأ ديته، فلذللك معنى المعرة في هذا الموضع الكفارة.

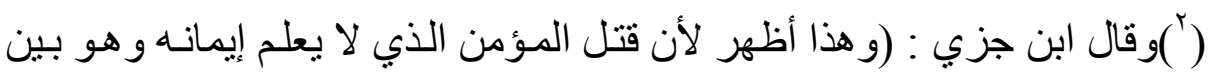

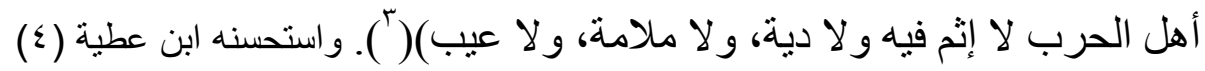

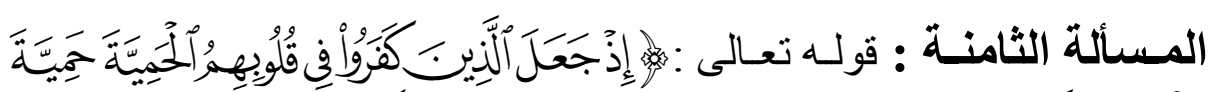

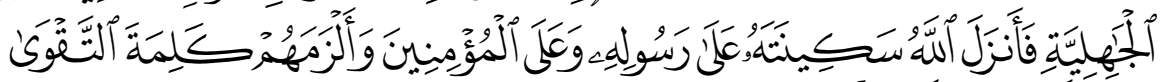

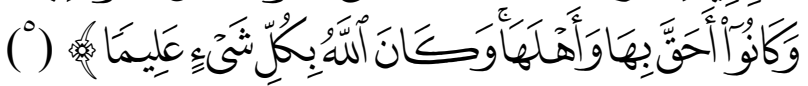

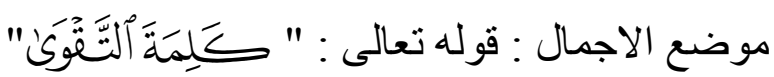

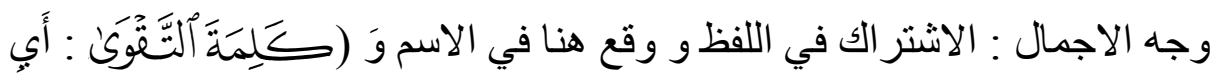

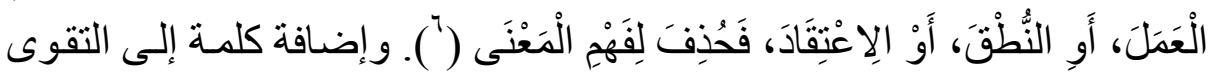

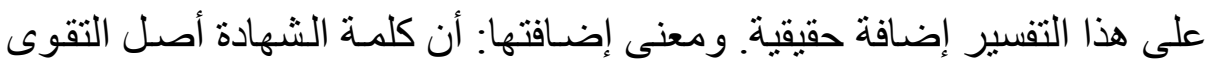
فإن أساس النقوى اجتناب عبادة الأصنام، ثم تتفرع على ذلك شعب التهاب التقوى كلها

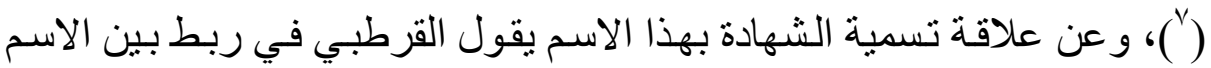

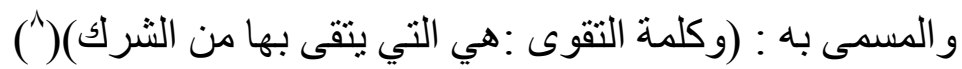

$$
\begin{aligned}
& \text { (1) سورة النساء : آية : ب (1) }
\end{aligned}
$$

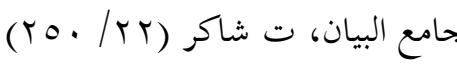

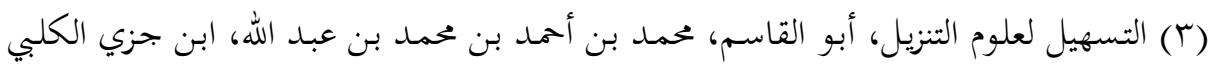

$$
\begin{aligned}
& (r q \cdot / r)
\end{aligned}
$$

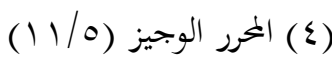

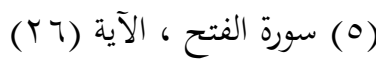

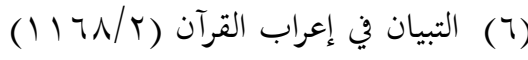

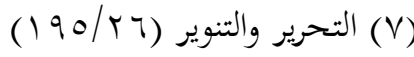

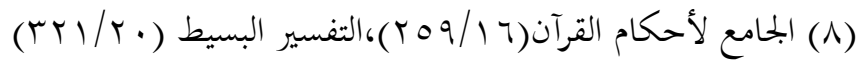

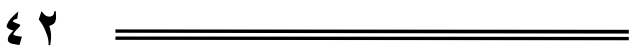


التوجيه و البيان :فيها أربعة أوجه: أحدها: قول لا إله إلا الله، قالـه ابن عباس

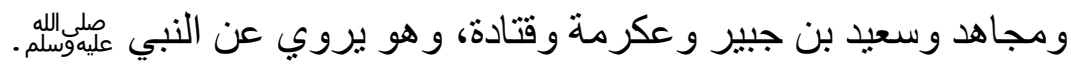
الثاني: الإخلاص، قاله مجاهد، فإنها السبب الأقوى و هي كل قول أو فعل ناثشى

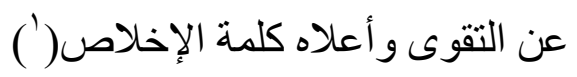
الثالث: قول بسم الله الرحمن الرحيم، قاله الزهري. الر ابع: قولهم سمعنا و أطعنا بعد خوضهم. الخامس: 》الا إله إلا الله و الله أكبر)، قالـه ابن عمر. و وعن علي بن أبي طالب

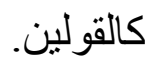
الساد: 》الا إله إلا الله وحده لا شريك له، لـه الملك وله الحمد و هو على كل شيء قدير «، قاله عطاء بن أبي رباح. السابع: (الا إله إلا الله محمد رسول الله)، قاله عطاء الخر اساني(r). والذي عليه الأكثرين من أهل التفسير أن كلمـة التقوى هي كلمـة التوحيد وهي ذاتها كلمة الاخلاص و الخلاف المتقدم أكثره لفظي.

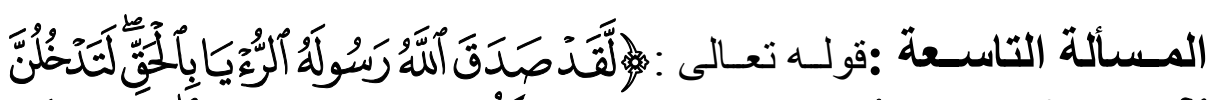

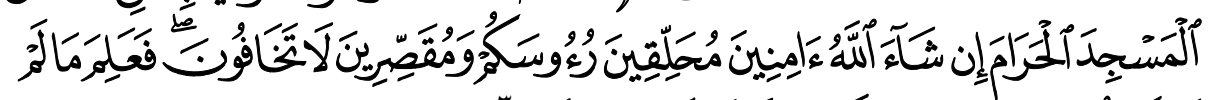

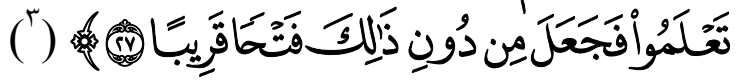

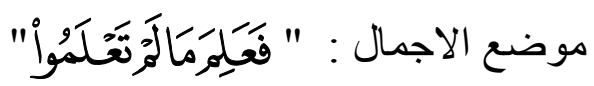

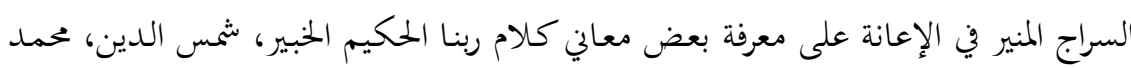

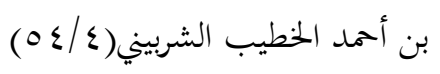

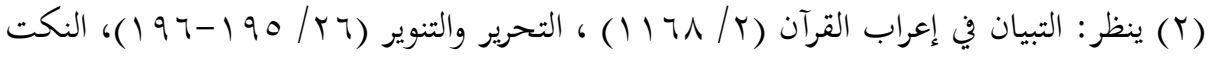

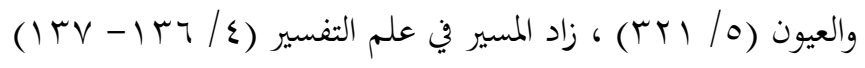

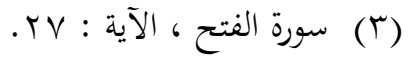




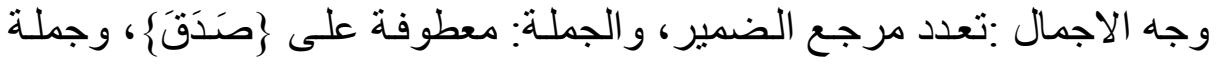
نعلَ

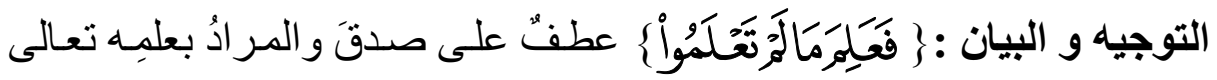

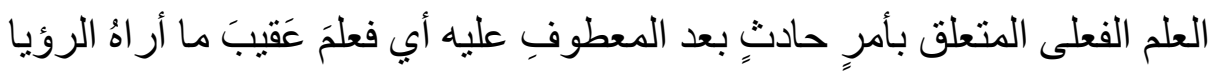

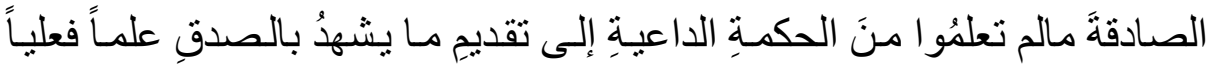

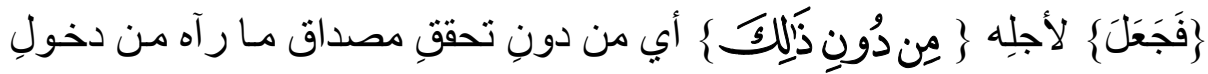

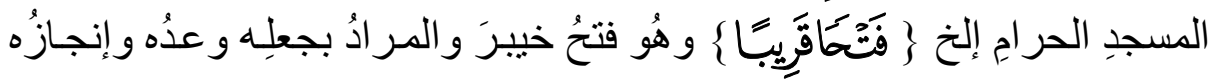

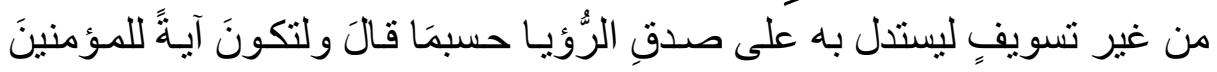

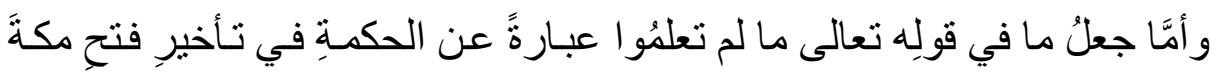

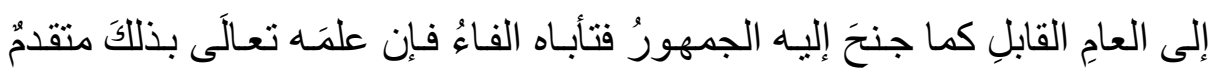

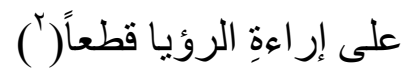

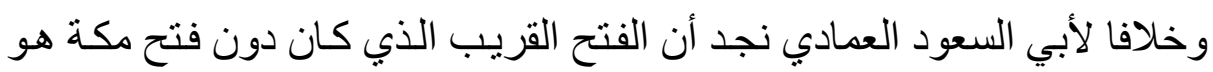

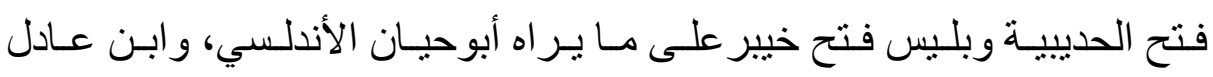
و الإيجي أنه الأصح عند الأكثرين(")

قال ابن جرير : و ذللك علمه تعالى ذكره بما بمكة من الرجال و النساء المؤمنين لم

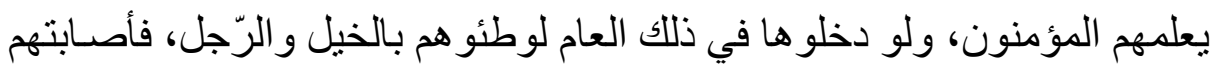

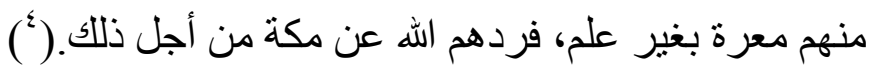

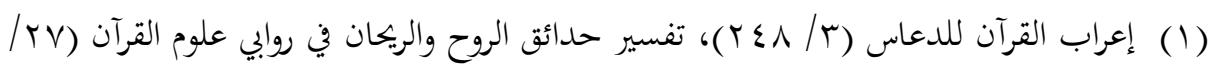
(r)人

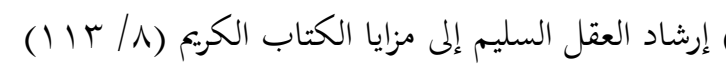

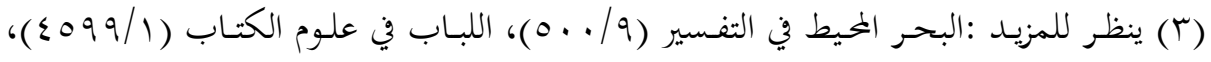

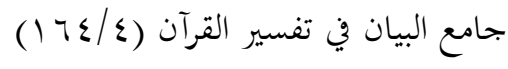

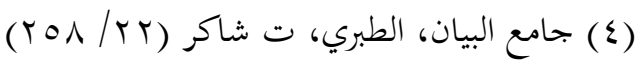


فعلم الله ما لم يعلم أحد من الحكمة في تأخير ذلك، من المصلحة في الصلح، لماـ في دخولكم في عام الحديية من الضرر على المستضعفين من المؤمنين (').

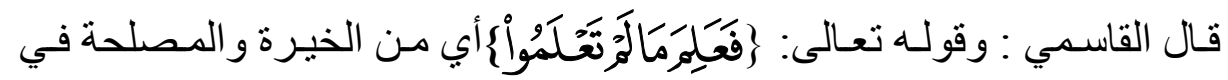

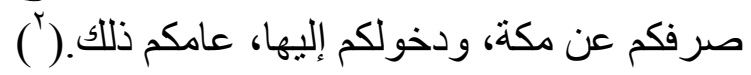

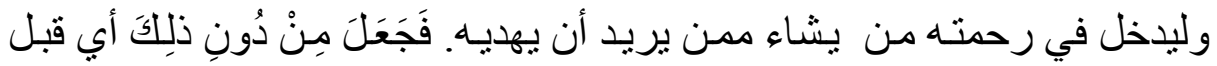

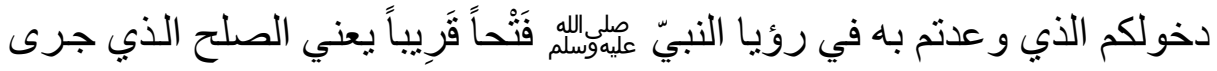

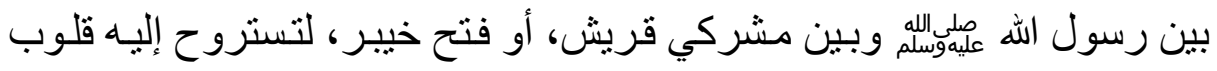
المؤمنين، إلى أن يتيسر الفتح الموعود. (")

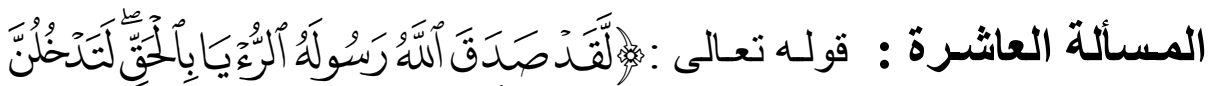

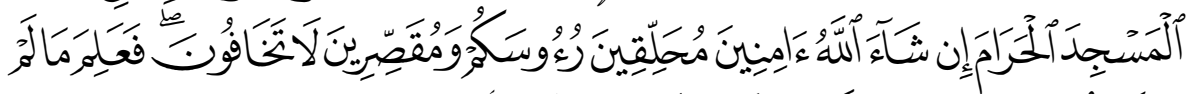

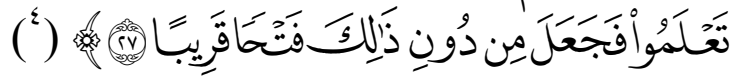

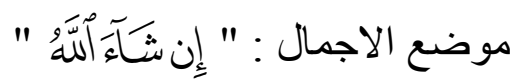
وجه الاجمال : الاشتر اك في اللفظ و هنا الاشتر الك كان في الحرف (إن) هل هي ألهاء

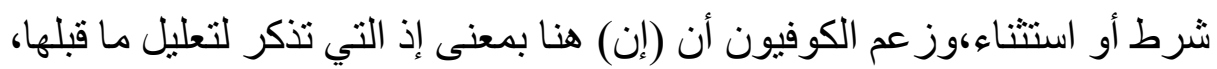

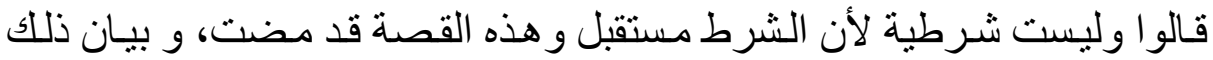
سيأتي.

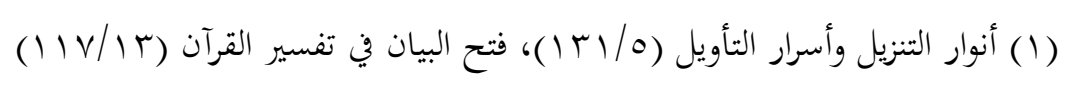

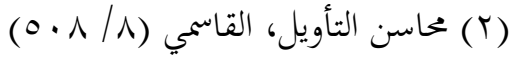

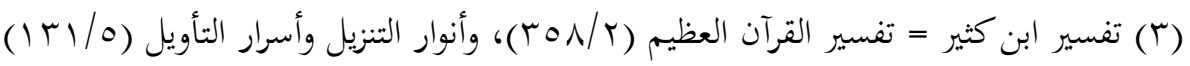

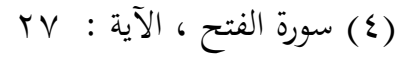


البيان و التوجيهه : واختلف الناس في معنى الاستثناء في هذه الآيـة، قـال أبو

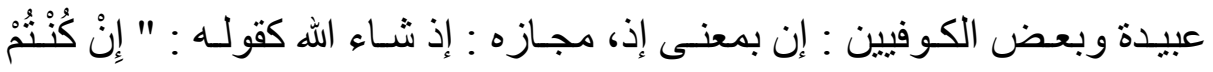

مُؤْنِنِنَ

و قال الحسين بن الفضل :يجوز أن يكون الاستثناء من الدخول، لأن بين الرؤيا

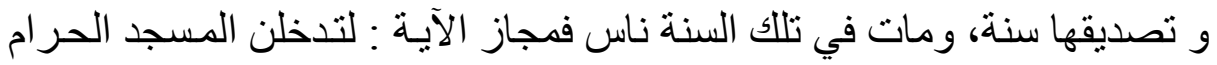
كلكم إن شاء الله.

و قيل : الاستثناء واقع على الأمن لا على الدخول، لأن الدخول لم يكن فيه شك،

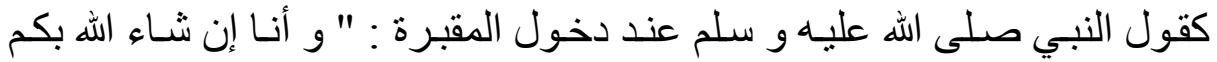

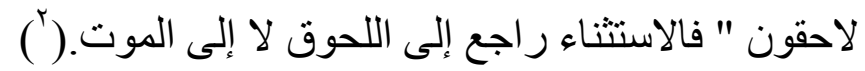
وفي تعليق الو عد بالمشيئة مع أنه تعالى خالق للأشياء كلها و عالم بها قبل وقو عها أقو ال نلخصها

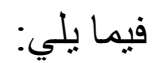
1 ـ أنه حكاية قول الملك للرسول عُلهوسلامه ، قاله ابن كيسان. rـ هذا التعليق تأدب بآداب الله تعالى و إن كان المو عود به محقق الوقوع حيث قال تعالى 》او لا تقولن لثيء إني فاعل ذلك غدا إلا أن يشاء اللهابه.

(1) ينظر: إعراب القرآن للأصبهاني، إسماعيل بن محمد بن الفضل بن علي القرشي الطليحي

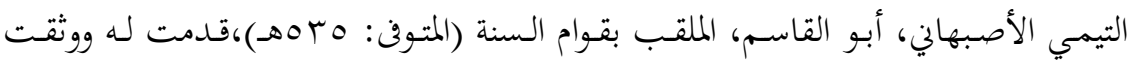

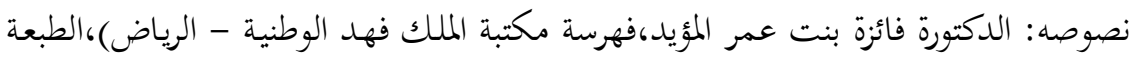

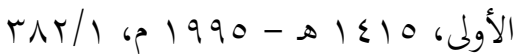

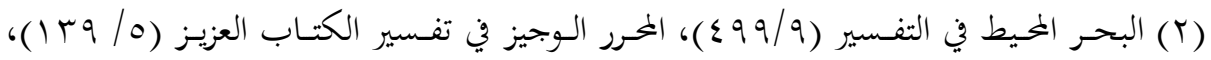

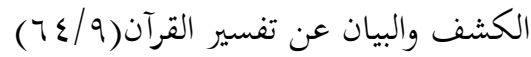


r- ـ وقال ثعلب استثنى فيما يعلم ليستثني الخلق فيما لا يعلمون('). ع - و أصح ما يقال ما أورده الزمخشري ونصه: اإن وجه دخول إن شاء الله في إخبار الله عزّ وجلَ أن يعلق عدّته بالمشيئة تعليما لعباده أن يقولو ا في عداتهم مثل ذلك متأدبين بأدب الله ومقتدين بسنّاهی). فلما نزلت هذه الآية علم المسلمون أنهم سيدخلونها فيما يستأنف، فاطمأنت قلوبهم

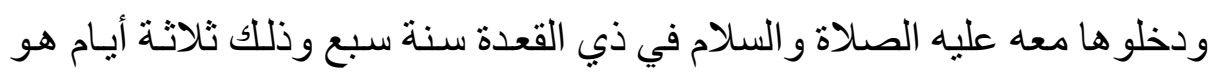

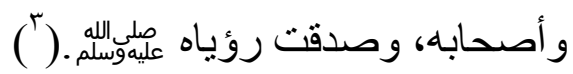

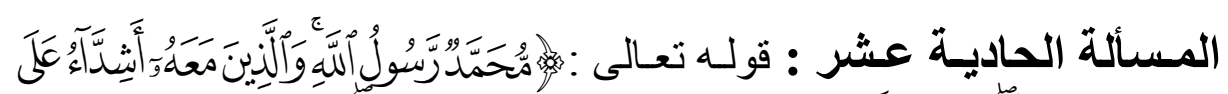

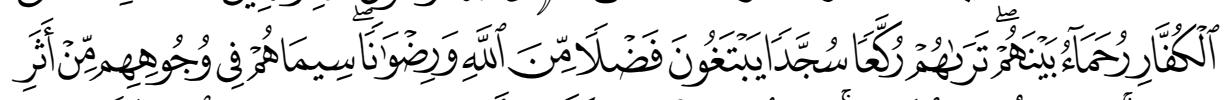

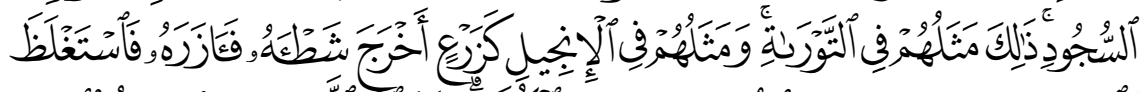

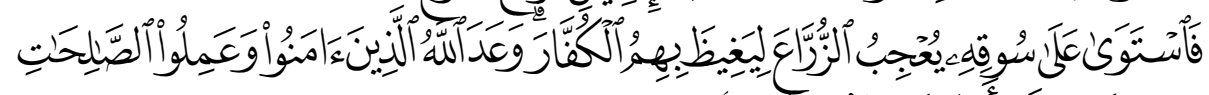

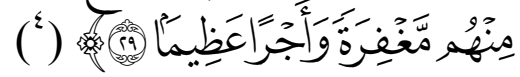

$$
\text { موضع الاجمال : " سِيمَاهُمُ" }
$$

وجـه الاجمـال : الاشتر اك في اللفظـ و الاشتر اك هنـا كـان في الاسم في قولـه " سيماهم " مجنه الاجم

فيه ثلاث لغات: السيما و السيماء و السيمياء، وهي لغة فصيحة كثيرة في الشعر،

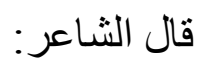

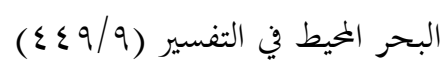

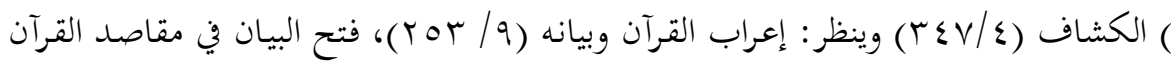

$$
\begin{aligned}
& \text { ( } 11 \mathrm{~V} / \mathrm{Tr})
\end{aligned}
$$

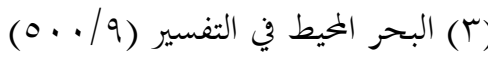

$$
\begin{aligned}
& \text { سورة الفتح ، الآية وجن. }
\end{aligned}
$$




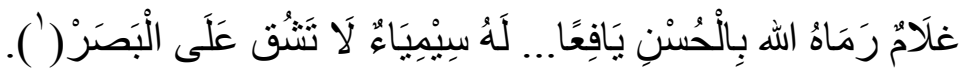

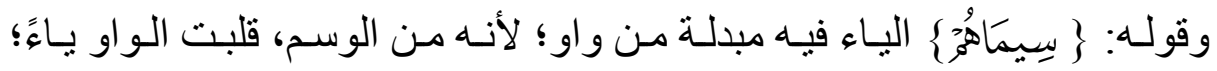

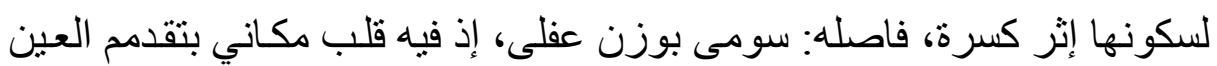

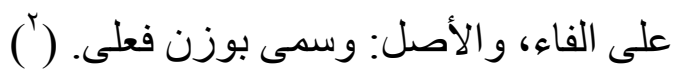

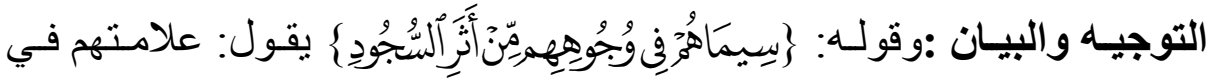
وجو ههم من أثر السجود في صلاتهم. ثم اختلف أهل التأويل في السيما الذي عنداه الله في هذا الموضع.

1/فقال بعضهم: ذللك علامة يجعلها الله في وجوه المؤمنين يوم القيامـة، يعرفون

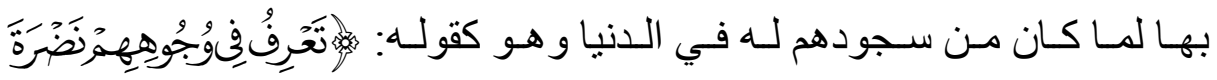

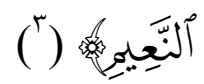
وفي هذه السيمياء أي العلامة الو اردة في الآيـة أقو ال كثيرة استجمعها الطبري،

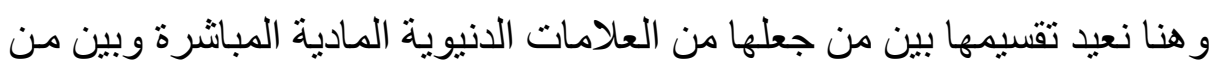
جعلها من علاماتهم في الآخرة. أما الأقو ال التي عدت هذه السيمياء في الدنيا فتنلخص بما يلي : ' ـ سيما الإسلام وسمته وخشو عه، و عنى بذللك أنه يرى من ذلك عليهم في الدنبا

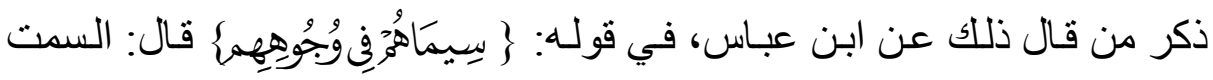

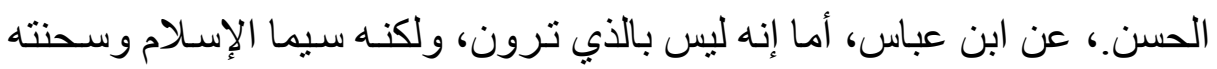

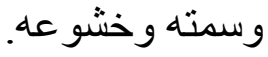

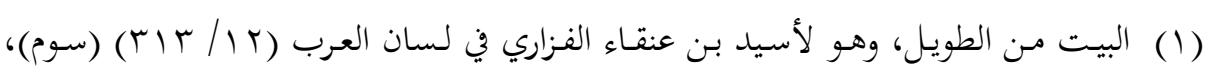

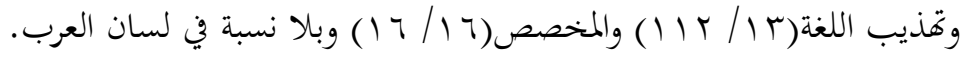

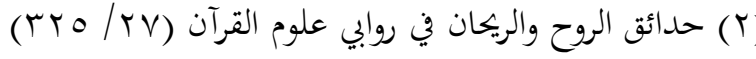

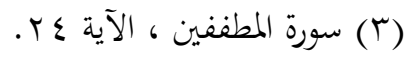




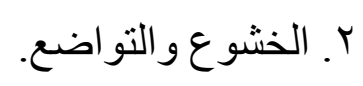

rـ إنه يكون بين عينيه مثل ركبة العنز، وهو كما شاء الله.

ع. ذلك أثر يكون في وجوه المصلين، مثل أثر السهر، الذي يظهر في الوجه مثل

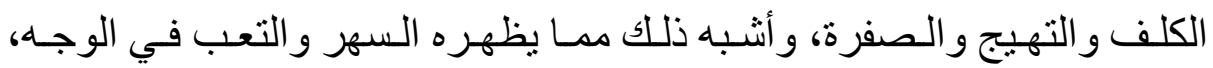
ووجهوا التأويل في ذللك إلى أنه سيما في الدنيا. 0. ذلك آثار ترى في الوجه من ثرى الأرض، أو ندى الطهور و هو أثز التراب. أما من رآى أن تلك العلامات في الاخرة فيرونها تتمثل بما يلي : ا ـ أن مواضع السجود من وجو ههم يوم القيامة أنثد وجو ههم بياضا.

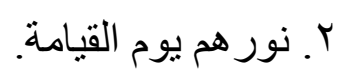

يقول الطبري : و أولى الأقوال في ذلك بالصو اب أن يقال: إن الله تعالى ذكره

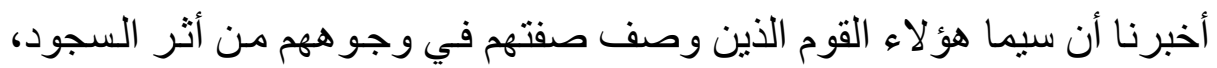
ولم يخصّ ذلك على وقت دون وقت.

و إذ كان ذلك كذللك،-يقصد بقاء المطلق على اطلاقهـ فذللك على كلّ الأوقات،

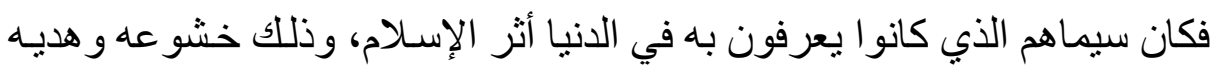

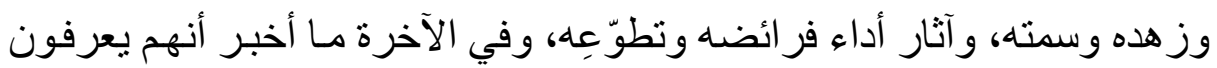

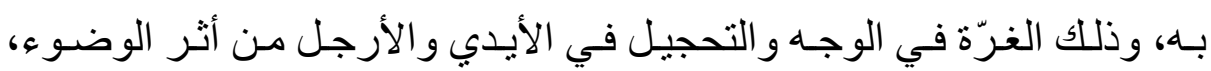
وبياض الوجوه من أثر السجود.(')

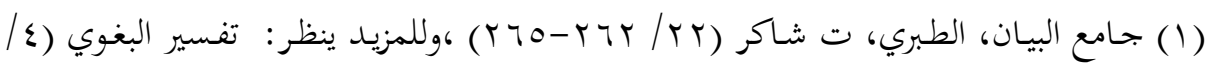

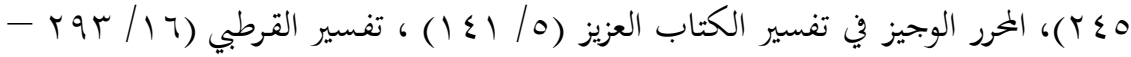

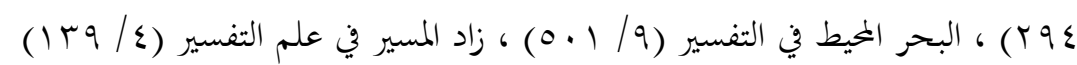


خلاصة القول أن سيمياء السجود في الدنيا أثر ذلك على وجه المؤمن من السمت

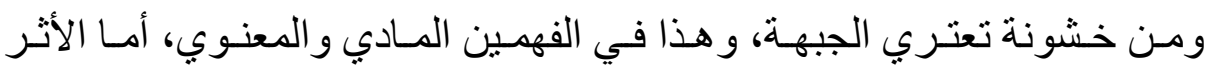
الأخروي فهو النور والبياض الذي يعرفون بهاه.

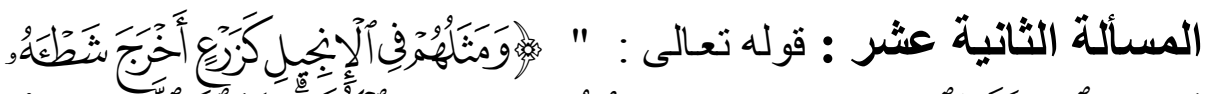

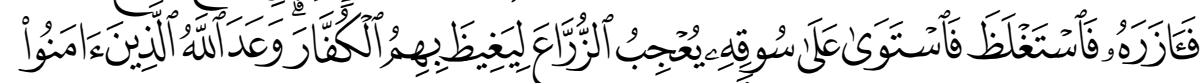

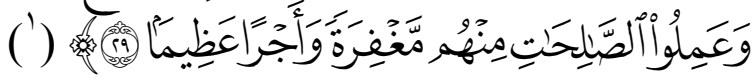

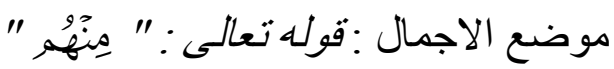
وجه الاجمال :الاشتر الك في الحرف (من) هل هي للتبعيض أو للبيان ؟

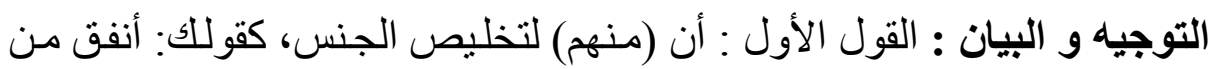

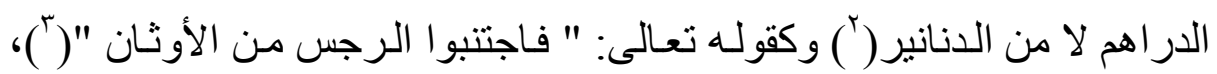

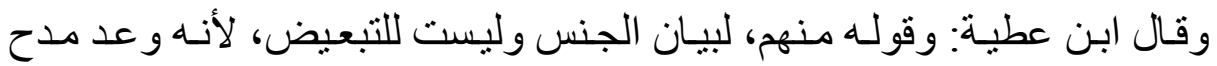

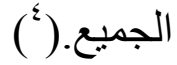
وقال ابن جرير: (منهم يعني: من الثطء الذي أخرجه الزرعُ و وهم الداخلون في

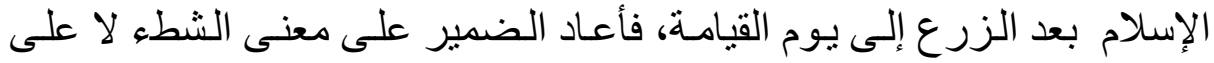

(). (لفظه). (الإنام

$$
\begin{aligned}
& \text { (1) سورة الفتح ، الآية : 9 ب. }
\end{aligned}
$$

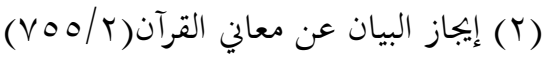

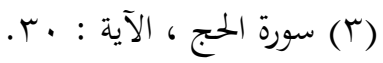

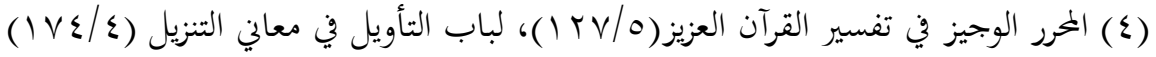

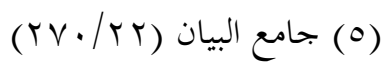


وجـاء في روح المعـاني : (أن الإمـام مالكـا قد استتبط مـن هـذه الآيــة تكفير الرو افض الذين يبغضون الصحابة رضي الله تعالى عنهم، فإنهم يغيظونهم ومن الإنس

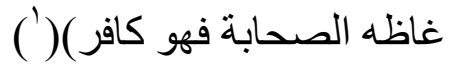

القول الثاني : أن يكون هذا الوعد لمن أقام منهم على الإيمـان و العمل الصالح،

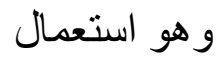

كثير، ويجوز إبقاؤه على ظاهر المعنى من التبعيض لأنه و عد لكل من يكون مع

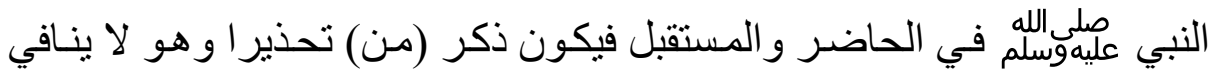

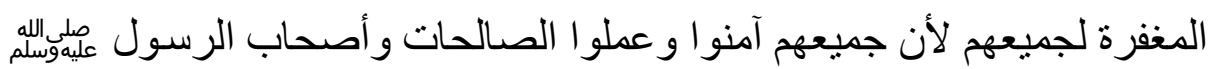

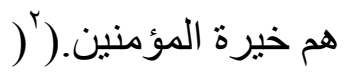

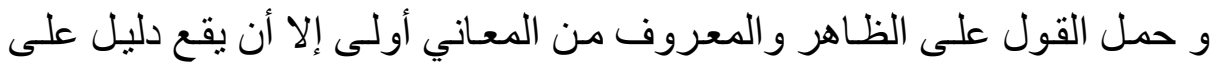
غير ذلك، و هنا نجد الكثرة من المفسرين مع القول بظاهر المعنى.

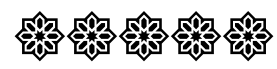

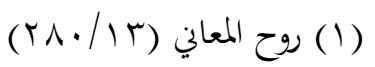

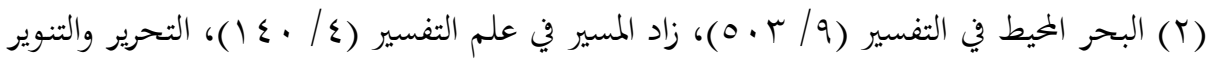

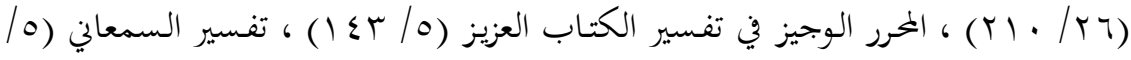

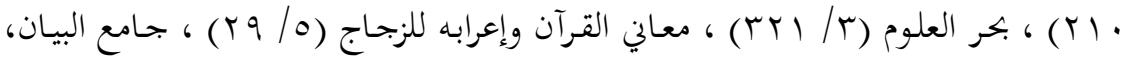

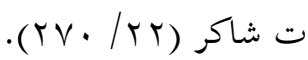




\section{الخاتهة}

الحمد لله الذي وفقني للنظر في كتابه وتدبر آياته، فقد أتاحت لي هذه الدراسة

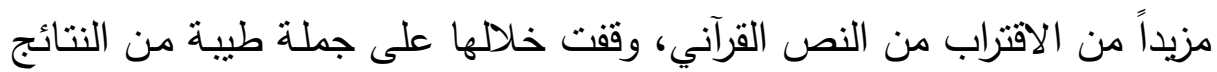

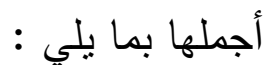

ا ـ يعد أسلوب القرآن في المجمل والمبين أسلوباً يجعل القرآن مدعاة لمداومة النظر فيه وتحفيزاً على تدبره.

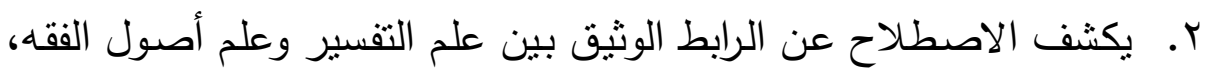

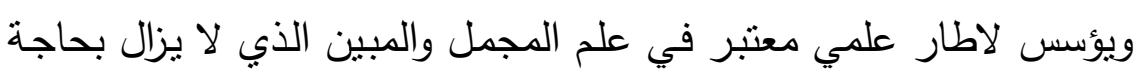
إلى عناية المختصين والهتمامهر فيه. r. ييرز بيان المجمل التفاوت بين المفسرين ومناهجهم في التفسير ومصادرهم في تحقيق المعاني القرآنية.

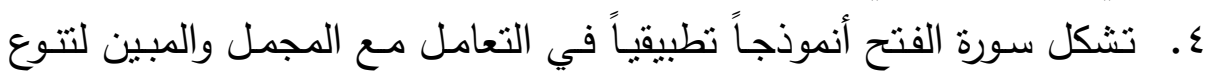
وجوه الاجمال في ألفاظ السورة.

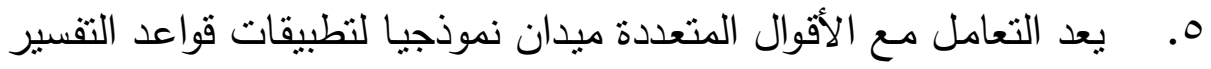

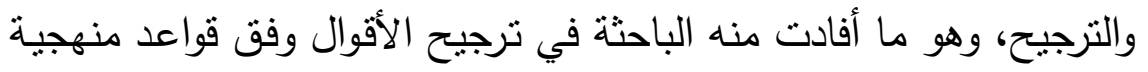
منضبطة.

وفي الختام أوصي بزيادة الاهتمام بمباحث أصول الفقه الخادمة والميسرة للتفسير

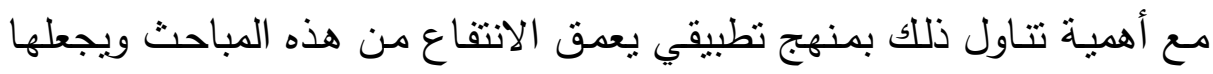
ميسرة للوصول لمراد الله في كتابه العزيز .

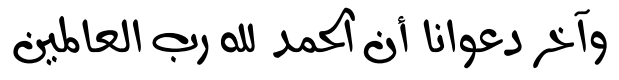




\section{قائمة المصادر والمراجع}

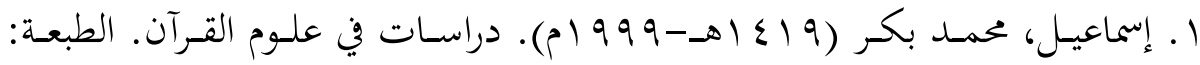

$$
\text { الثانية. دار المنار }
$$

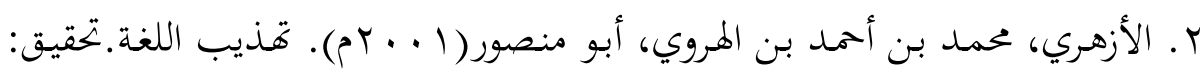

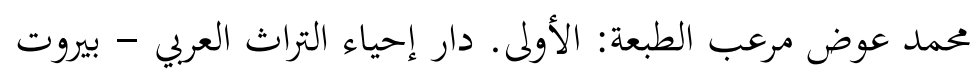

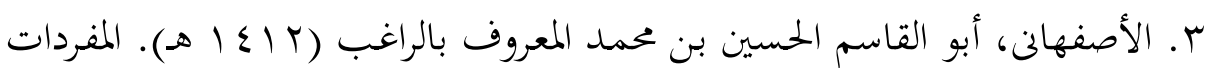

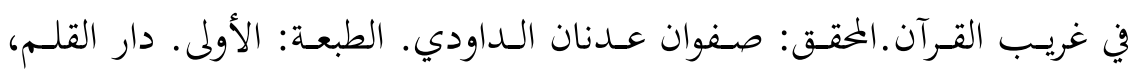

$$
\text { الدار الشامية - دمشق بيروت }
$$

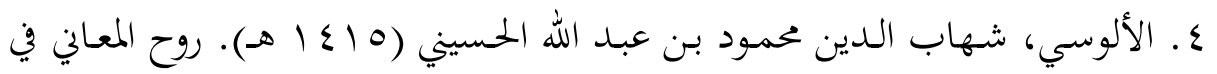

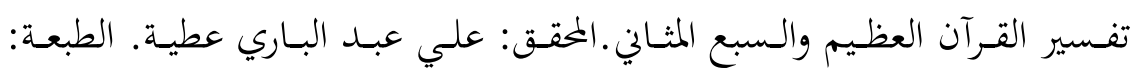

$$
\text { الأولى. دار الكتب العلمية - بيروت. }
$$

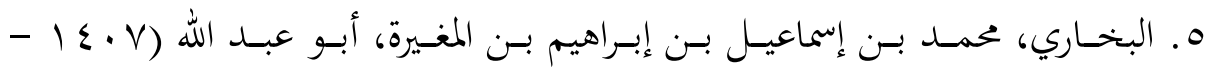

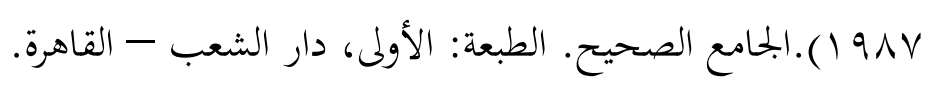

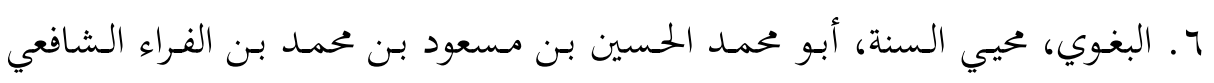

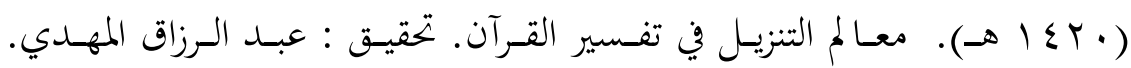

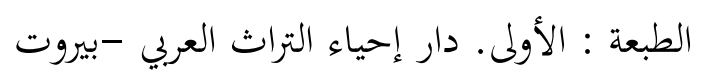

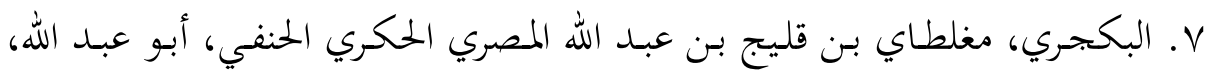

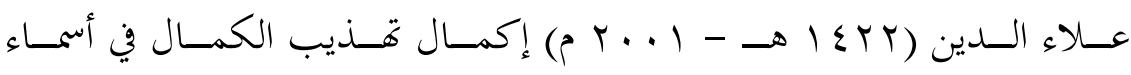

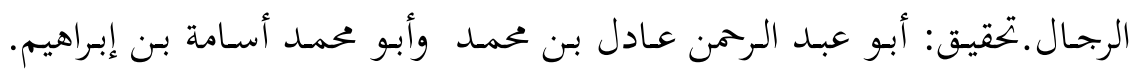

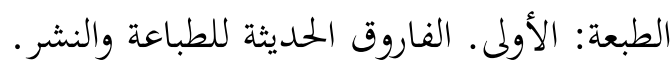


م. البيضاوي، ناصر الدين أبو سعيد عبد الله بن عمر بن محمد الشيرازي (1 إـ اهـ). أنوار التنزيل وأسرار التأويل. المحقق: محمد عبد الرحمن المرعشلي. الطبعة: الأولى.

$$
\text { دار إحياء التراث العربي - بيروت }
$$

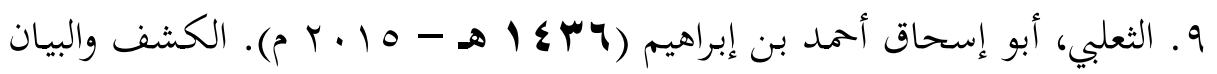

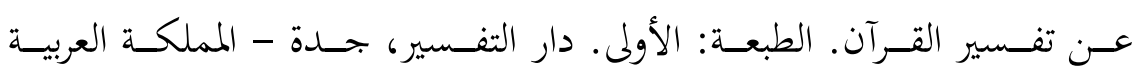

$$
\text { السعودية. }
$$

• 1 ابن جزي الكلبي، أبو القاسـم، محمد بن أحمد بن محمد بن عبد الله، الغرناطي (7 ا ع 1 هـ). التسهيل لعلوم التنزيل.المحقق: الدكتور عبد الله الخالدي. الطبعة:

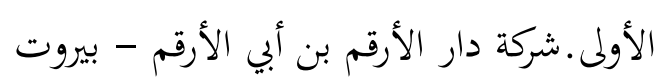

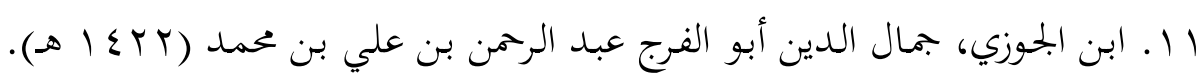

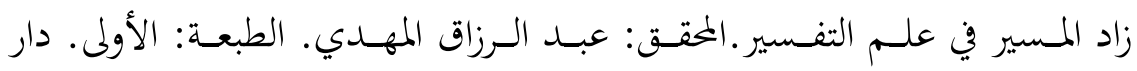

$$
\text { الكتاب العربي - بيروت. }
$$

ب ا ـ الحموي، أحمد بن محمد بن علي الفيومي ثم الحموي، أبو العباس،المصباح المنير

$$
\text { في غريب الشرح الكبير. المكتبة العلمية - بيروت. }
$$

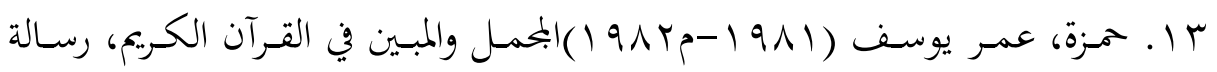
ماجستير، إشراف د. محمد أبو النور الحديدي، جامعة أم القرى. مكة المكرمة. ع ا. أبو حيان، محمد بن يوسف بن علي بن يوسف بن حيان أثير الدين الأندلسي

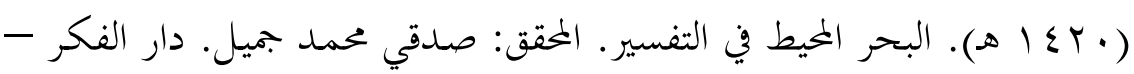

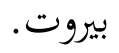

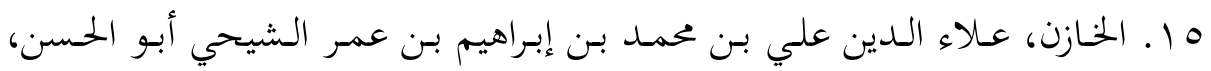

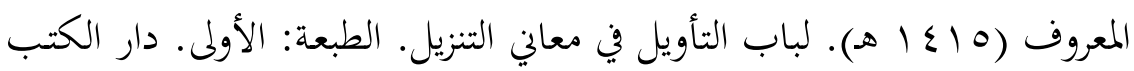

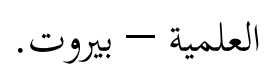

\section{๑}




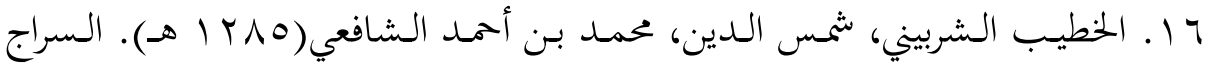

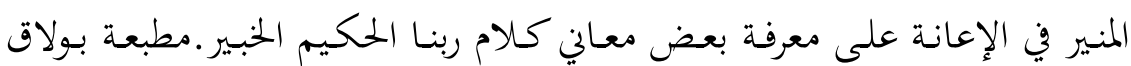

$$
\text { (الأميرية) - القاهرة. }
$$

V ا ـ الرازي، أبو عبد الله محمد بن عمر بن الحسن بن الحسين التيمي الرازي الملقب

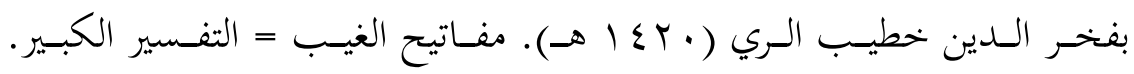

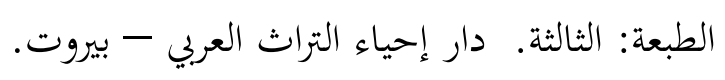

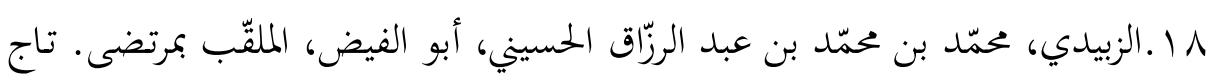

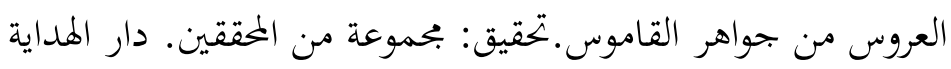

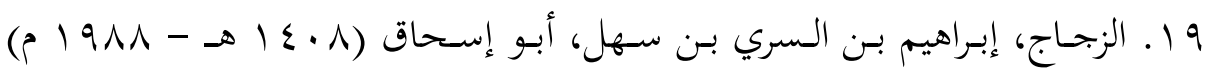

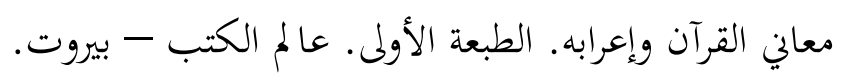

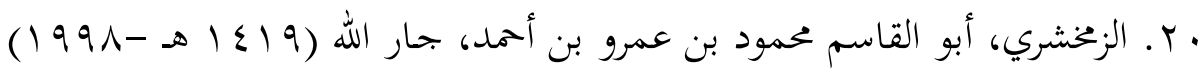

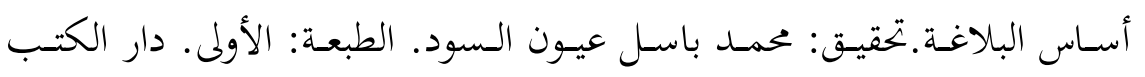

$$
\text { العلمية، بيروت - لبنان. }
$$

آب. الزخشري، أبو القاسم محمود بن عمر الخوارزمي. الكشاف عن حقائق التنزيل

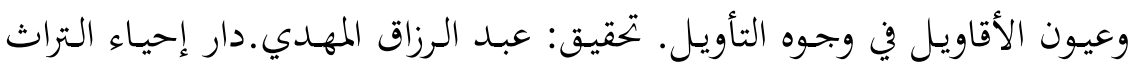

$$
\text { العربي - بيروت. }
$$

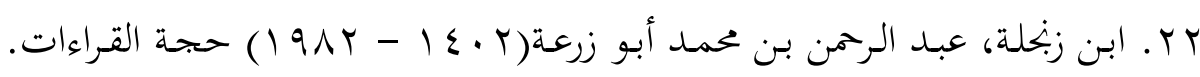

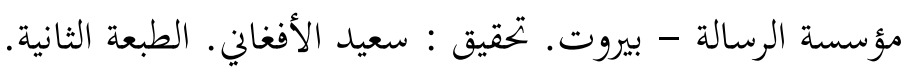

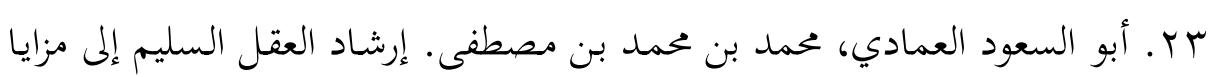

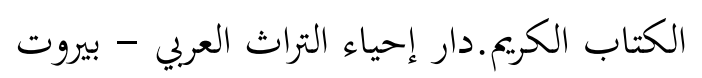


ع ז. السمعاني، أبو المظفر، منصور بن محمد بن عبد الجبار ابن أحمد المروزى التميمي

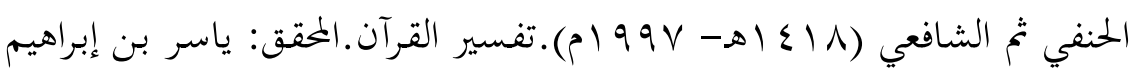

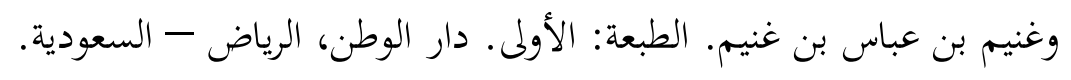

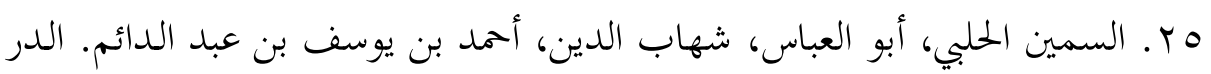

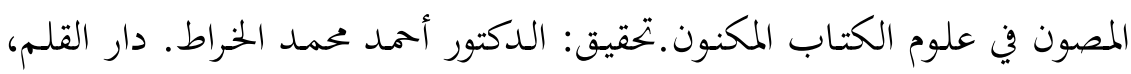

$$
\text { دمشق. }
$$

Tr. السمين الحلبي، أبو العباس، شهاب الدين، أحمد بـن يوسف بـن عبد الدائم

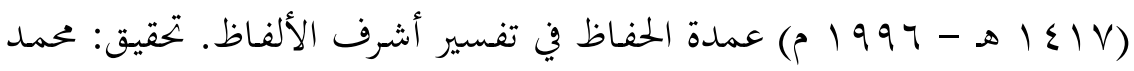

$$
\text { باسل عيون السود. الطبعة: الأولى. دار الكتب العلمية. }
$$

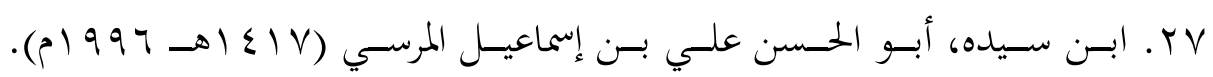

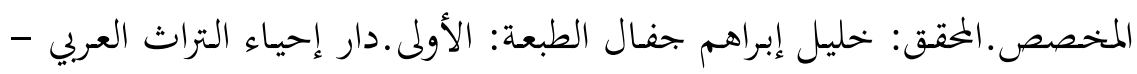

$$
\text { بيروت }
$$

^ץ. السيوطي، أبو الفضل جـلال الدين عبد الرحمن بن أبي بكر. الاتقان في علوم

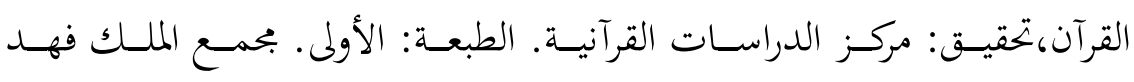

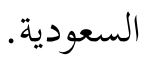

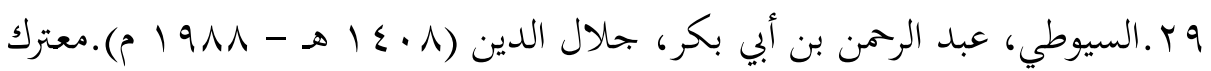

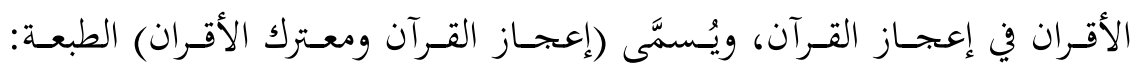

$$
\text { الأولى.دار الكتب العلمية - بيروت - لبنان. }
$$

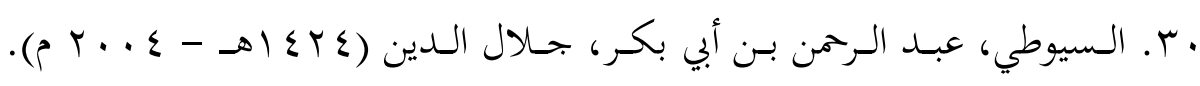

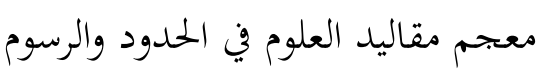

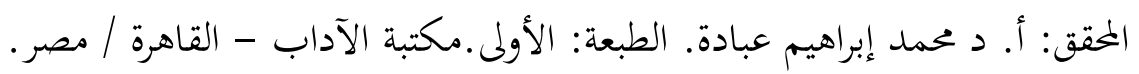




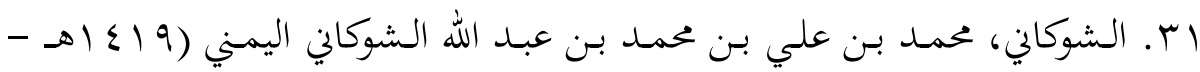

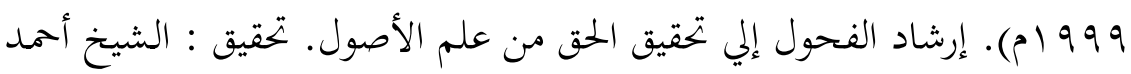
عزو عناية، دمشق - كفر بطنا. الطبعة الأولى.دار الكتاب العربي.

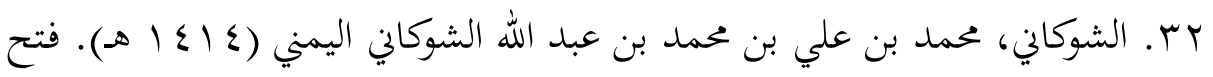

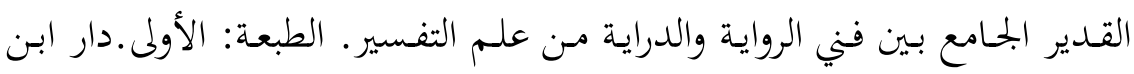
كثير، دار الكلم الطيب - دمشق، بيروت.

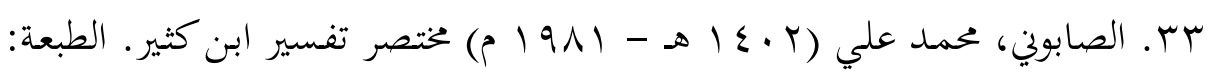

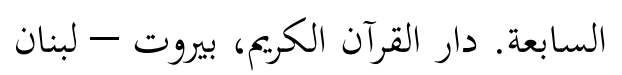

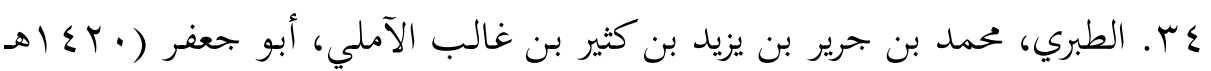

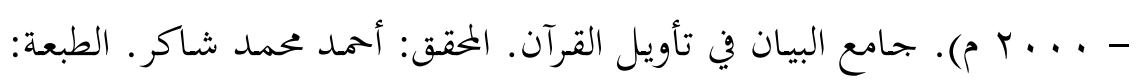

$$
\text { الأولى. مؤسسة الرسالة. }
$$

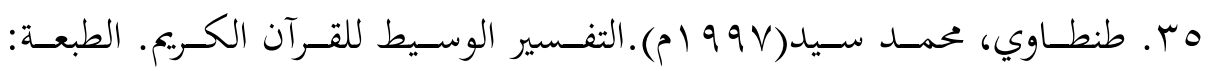

$$
\text { الأولى.دار هضة مصر للطباعة والنشر والتوزيع، الفجالة - القاهرة. }
$$

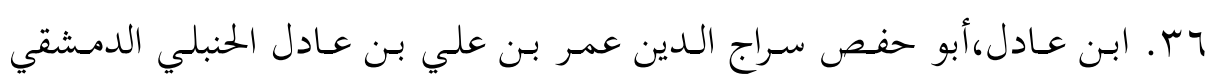

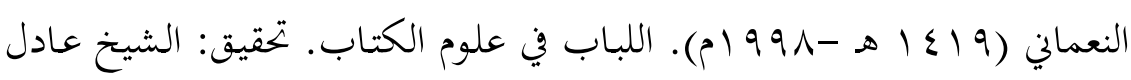

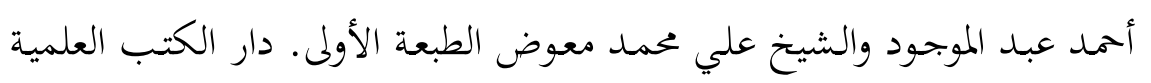

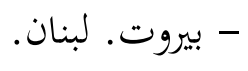

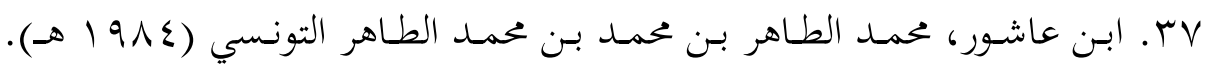

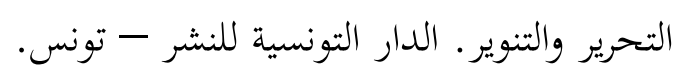

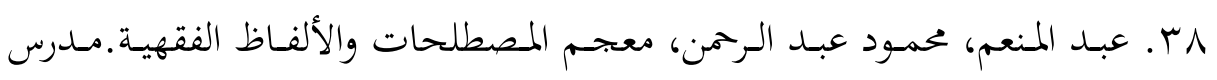
أصول الفقه بكلية الشريعة والقانون - جامعة الأزهر. دار الفضيلة. 


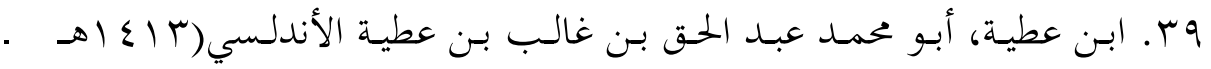

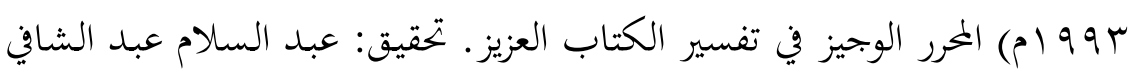
محمد. الطبعة الأولى. دار الكتب العلمية.لبنان.

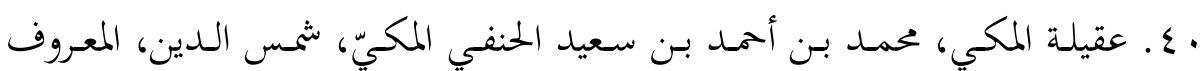

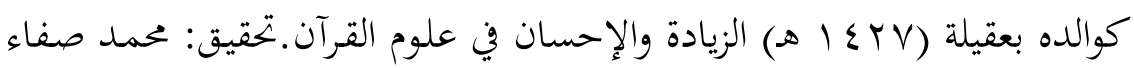

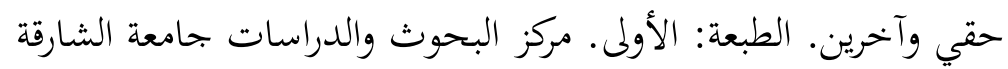
اءـ العكبري، أبو البقاء عبد الله بن الحسين بن عبد الله. التبيان في إعراب القرآن. تحقيق :علي محمد البجاوي. الناشر : عيسى البابي الحلبي وشركاه.

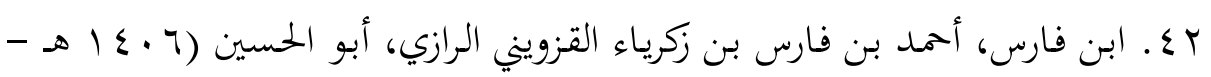
49191 م) بحمل اللغة. دراسة وتحقيق: زهير عبد المحسن سلطان. الطبعة الثانية. مؤسسة الرسالة - بيروت.

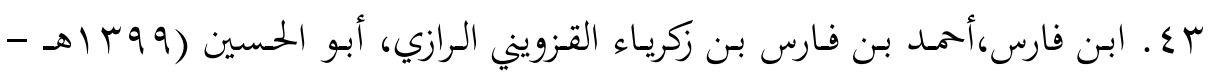

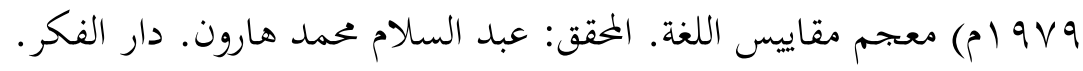

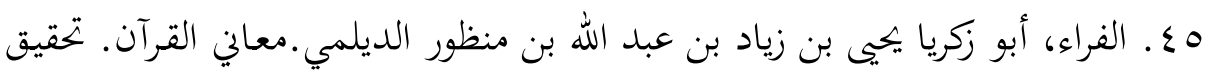

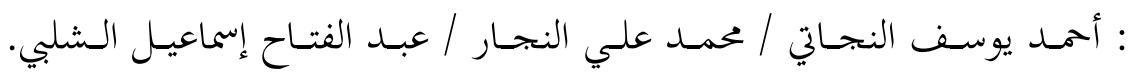

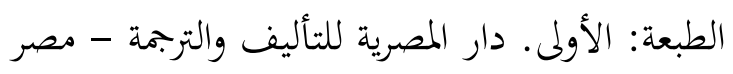

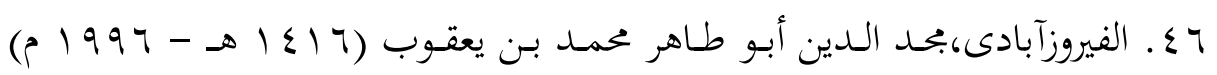

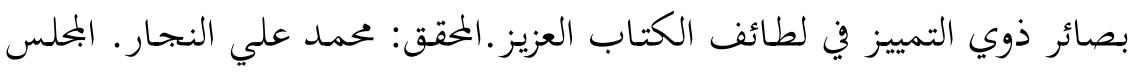
الأعلى للشئون الإسلامية - لمنة إحياء التراث الإسلامي، القاهرة.

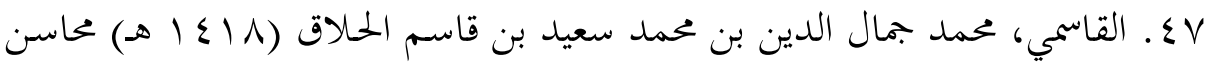

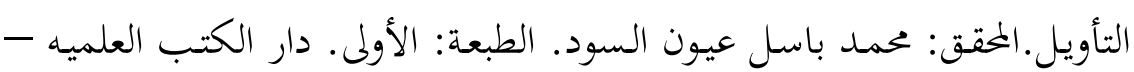


^ــ القرطبي، أبو عبد الله محمد بن أحمد بن أبي بكر بن فرح الأنصاري الخزرجي

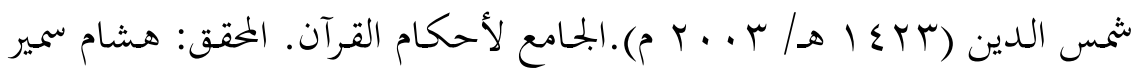

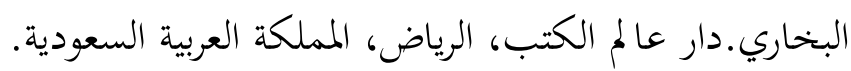

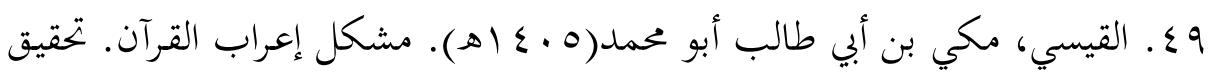

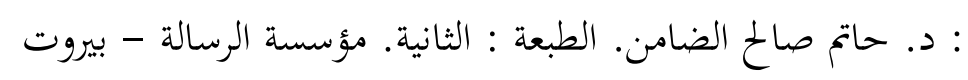

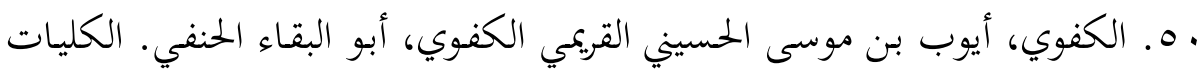

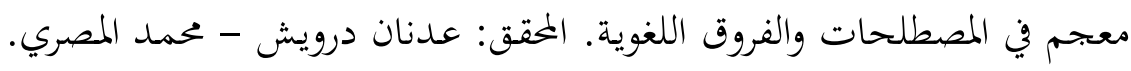

$$
\text { مؤسسة الرسالة - بيروت. }
$$

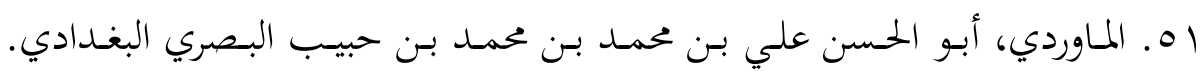

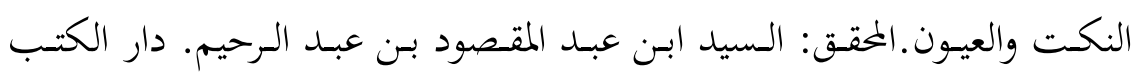

$$
\text { العلمية - بيروت. لبنان. }
$$

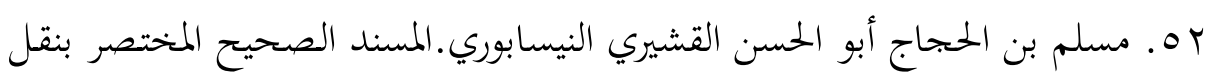

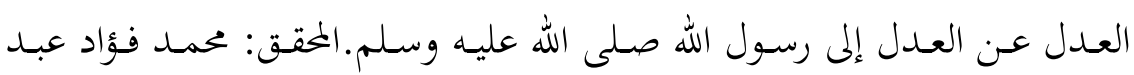

$$
\text { الباقي. دار إحياء التراث العربي - بيروت. }
$$

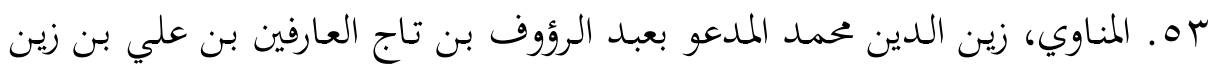

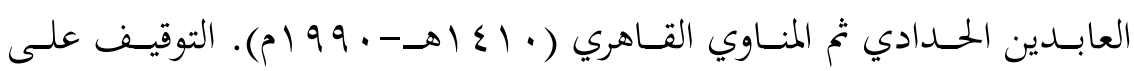
مهمات التعاريف. الطبعة: الأولى.عالم الكتب. عبد الخالق ثروت-القاهري القاهرة

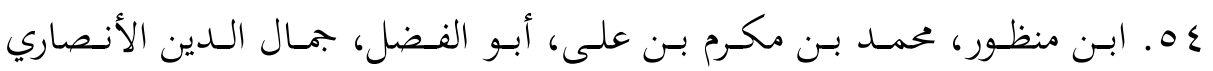

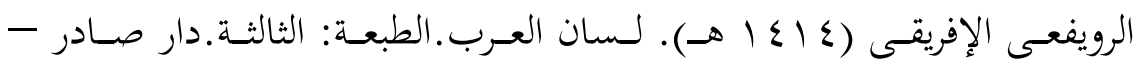

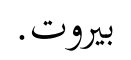

ه. النحاس، أبو جعفر أحمد بن محمد بن إسماعيل النحاس. إعراب القرآن. تحقيق:

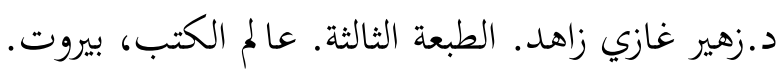




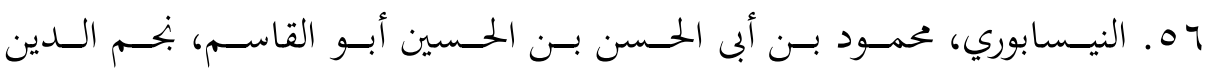

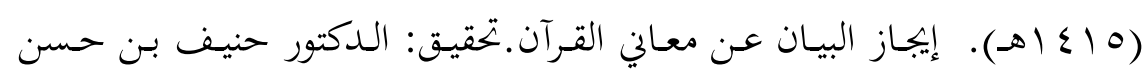

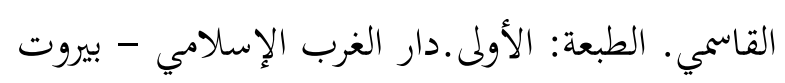

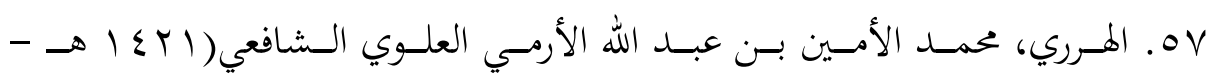

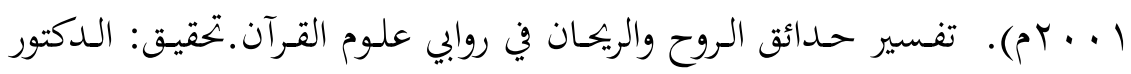

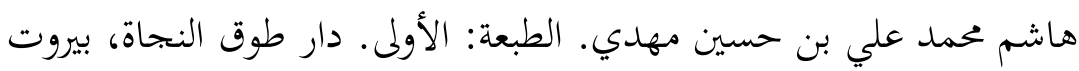

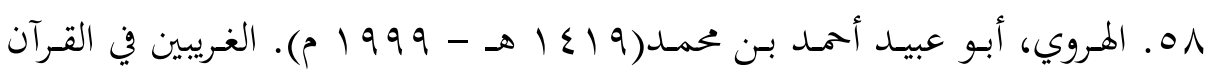

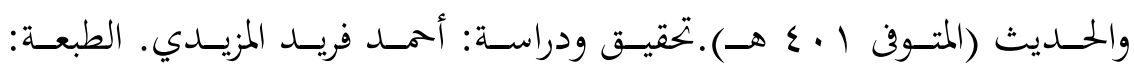

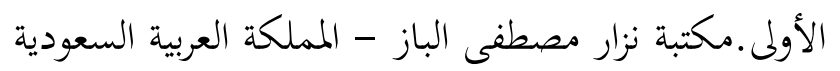

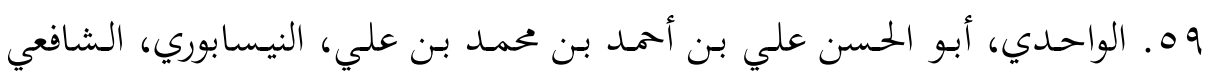

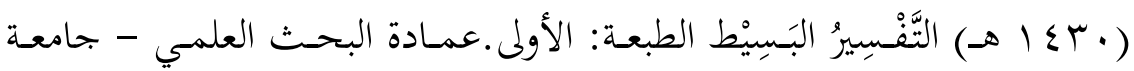

$$
\text { الإمام محمد بن سعود الإسلامية. }
$$

